\title{
MONETARY POLICY AND THE FLOW OF FUNDS IN THE EURO AREA
}




\title{
WORKING PAPER SERIES
} NO I402 / DECEMBER 20 II

\section{MONETARY POLICY AND THE FLOW OF FUNDS IN THE EURO AREA'}

\author{
by Riccardo Bonci ${ }^{2}$
}
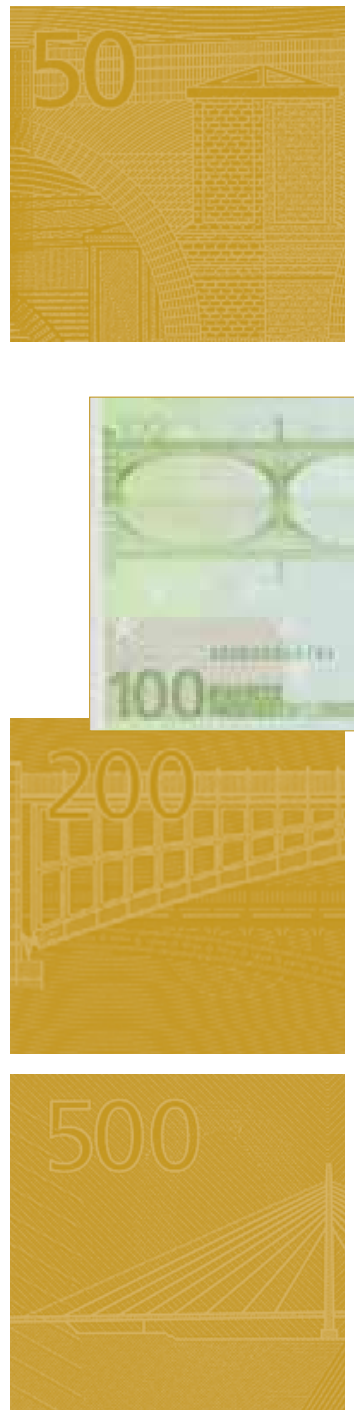

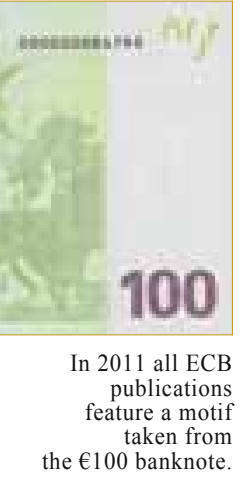

This paper can be downloaded without charge from http://www.ecb.europa.eu or from the Social Science Research Network electronic library at http://ssrn.com/abstract_id $=1956460$.

I The first version of this paper was drafted during a stay at the ECB, in the Monetary Policy Stance Division. I thank B. Fischer, B.* reta, M. Lenza, $\square$. Musso, M. Tujula, B. Winkler, T. Westermann and participants at two ECB seminars for very helpful suggestions and discussions. $\square A l l$ errors are mine. The views expressed here are those of the author and do not necessarily reflect those of the Banca d'Italia 
(C) European Central Bank, 2011

\section{Address}

Kaiserstrasse 29

60311 Frankfurt am Main, Germany

Postal address

Postfach 160319

60066 Frankfurt am Main, Germany

Telephone

+496913440

Internet

http://www.ecb.europa.eu

Fax

+496913446000

All rights reserved.

Any reproduction, publication and reprint in the form of a different publication, whether printed or produced electronically, in whole or in part, is permitted only with the explicit written authorisation of the ECB or the author.

Information on all of the papers published in the ECB Working Paper Series can be found on the ECB's website, http://www. ecb.europa.eu/pub/scientific/wps/date/ html/index.en.html

ISSN 1725-2806 (online) 


\section{CONTENTS}

Abstract

Non-technical summary

1 Introduction

2 Monetary policy transmission in the euro area

3 The benchmark VAR model

3.1 The impact of a monetary policy shock on the economy

3.2 Robustness analysis

3.3 The effect of monetary policy shocks on other macro variables

4 Monetary policy and the flow of funds

4.1 The euro-area flow of funds

4.2 Borrowing and lending after a policy tightening

4.3 The response of credit growth

5 Conclusion

References

Appendix 


\begin{abstract}
This paper provides new evidence on the transmission of monetary policy in the euro area, assessing the impact of an unexpected increase of the short-term interest on the lending and borrowing activity of the different economic sectors. We exploit the information content of the flow-of-funds statistics, that provide the most appropriate framework to analyse the flowing of funds from one sector (the lender) to the other (the borrower). We proceed in two steps. First, we estimate a small VAR model for the euro area over the period 1991Q1 to 2009Q2. Then, we extend the benchmark VAR model in order to include the flow-of-funds series and analyse the response of the latter variables to a contractionary monetary policy shock. We find that the policy tightening is followed by a worsening of the budget deficit; firms cut on their demand for bank loans, partially replacing them with inter-company loans, and draw on their liquidity to try to offset the fall of revenues associated with the slowdown of economic activity; households reduce net borrowing and increase precautionary saving in the short run. Consistent with the bank lending channel of monetary policy at work, the interest rate hike is followed by a short-run deceleration of credit growth, mainly driven by the response of banks.
\end{abstract}

JEL codes: E32, E4, E52, G11.

Keywords: euro area, monetary policy, flow of funds, credit growth. 


\section{Non-technical summary}

In order to understand how monetary policy affects the economy, it is very important to know if and how an unexpected change in the short-term interest rate has an impact on households' and firms' financial investment choice and new debt issuance, because these variables, in turn, are strictly related to their ability to consume and invest. The level of public deficit, requiring net borrowing by the government from the rest of the economy, might also be affected, with relevant consequences on the possibility for fiscal policy to provide the necessary stimulus in case of need.

Although these topics are relevant for both the transmission of monetary policy and for broader macro-prudential purposes, so far they have been scarcely addressed in the literature. Their knowledge has become even more urgent in the context of the recent financial crisis, where the level of debt (first private, then public) has clearly played a crucial role. A few exceptions to this shortage of information are the analyses available for the US and for Italy (respectively, Christiano et al. (1996), and Bonci and Columba (2008)). One possible reason is the rather limited data availability. In fact, the most appropriate statistical framework to address these issues would seem to be the flow-of-funds statistics, recording all financial transactions (not only those involving banks) among the economic sectors, but unfortunately such datasets are generally scarce and time series are often too short to allow for a proper econometric analysis. In the euro area, for instance, where quarterly flow-offunds series date back to 1999, an analysis based on this dataset has become feasible only recently.

This paper contributes to the empirical literature on the impact of monetary policy in the euro area, analysing the responses of the flow-of-funds variables to an interest rate tightening, in the vein of the seminal contribution by Christiano et al. (1996) for the US economy.

First we estimate a vector auto-regression (VAR) model to identify monetary policy shocks in the euro area. The impact of an interest rate tightening in our model is consistent with existing evidence for the euro area and with widely accepted theoretical prior: (i) output and prices decrease (the latter more persistently); (ii) consistent with a liquidity effect, money falls below the baseline; (iii) unemployment grows and labour productivity falls, resulting in a pro-cyclical response of the latter. The VAR model is then used to assess the response of the flow of funds to a monetary tightening. Besides net funds raised (i.e. net borrowing) by each sector, we also take into account some specific financial assets and liabilities in the case of households and firms. Due to the prominent role in the context of the ECB monetary policy strategy, we also examine the impact of a monetary policy shock on loans to the private sector, distinguishing between loans provided by banks and credit granted by other sectors.

Consistent with standard monetary business cycle models, following a one- 
standard deviation increase in the short-term interest rate firms cut both on their issuance of liabilities and on their acquisition of financial assets; the overall effect on net funds borrowed is negligible.

Households react to the worsened economic perspectives and to rising unemployment by reducing the issuance of new debt in the short run, at the same time increasing precautionary savings.

The public deficit widens significantly after the restrictive monetary policy shock, in line with the expected budget worsening due to lower tax receipts following the slowdown in economic activity induced by the interest rate hike and with the outlays related to the automatic stabilizers at work.

As regards the overall credit development, consistent with the lower credit demand associated with the slowdown in economic activity and with tighter credit standards as predicted by the bank lending channel of monetary policy, we find the contractionary policy shock to be associated with a significant fall in (short-term) loans to the private sector. This outcome can be ascribed to the bank component of loans, while loans granted by other sectors (especially to households) are found to increase after the policy tightening. The latter result is not necessarily counter-intuitive or puzzling as it might appear at first glance. For instance, households and firms might be able to draw from precommitted credit lines (at the pre-shock lower rate), at least in the short run. Moreover, the initial credit expansion could still be consistent with a credit crunch if loan demand is actually larger than loan supply after the shock.

All in all, the analysis based on the flow of funds shades new light on the transmission of monetary policy in the euro area.

\section{Introduction}

The vast literature which has attempted since Sims (1980) to assess the effect of monetary policy shocks on the economy employing vector auto-regression (VAR) models, has dealt only marginally with the borrowing and lending activity of the different economic sectors. Nevertheless, as Christiano et al. (1999) underlined "a contractionary monetary policy shock has differential effects on the borrowing and lending activities of different agents in the economy. [...] These findings have been used to help assess the empirical plausibility of competing theories of the monetary transmission mechanism". Thus, in order to understand the functioning of an economic system, we would need to answer also the following questions: to what extent (and how quickly) does monetary policy affect households' portfolio allocation or their new debt issuance? Do firms cut back on the demand for funds (loans, bonds, and shares) in the aftermath of an unexpected interest rate hike? What is the impact on the public deficit? To mention only a few. These issues became even more relevant with the 2007-2009 global financial crisis, after which a significant degree of de-leveraging is expected to take place in order to reduce the high 
debt accumulated by some sectors (especially governments and households) in certain countries.

While a fair amount of research is available on the impact of an interest rate change on loans or deposits (notably, Bernanke and Blinder (1992), Bernanke and Gertler (1995), Christiano et al. (1996), and den Haan et al. (2007) for the US economy; Giannone et al. (2009) for the euro area), so far financial transactions not involving the banking system have been much less investigated in the literature on monetary policy transmission. The information content provided by the flow of funds would seem to be the most appropriate for this kind of analysis, providing a comprehensive framework for the borrowing and lending activities involving any financial instrument between all the sectors of the economy (also those where banks are not a counterpart).

Christiano et al. (1996) were the first, to our knowledge, to employ the information content of the US flow of funds to assess the impact of monetary policy by means of an estimated VAR model. One of their main findings is that firms borrow more funds (in net terms) after the policy tightening; firms' net borrowing declines only one year later, when the slowdown in output induced by the policy shock gains momentum. Christiano et al. (1996) argued that this pattern was not captured by existing monetary business cycle models and suggested, as a possible explanation, firms' difficulty to adjust nominal expenditures once the fall in cash-flow materializes. They also found that net funds raised by households remain unchanged for several quarters after the shock, consistent with limited participation models of the type discussed in Christiano et al. (1997). Finally, they observed a (puzzling) lower public deficit in the short run, which they explained with a temporary increase of personal tax receipts.

Bonci and Columba (2008) applied a similar methodology to Italy. Differently from Christiano et al. (1996) they find that following a restrictive monetary policy shock non-financial corporations ${ }^{1}$ decrease both the acquisition of new financial assets and the issuance of new debt; in other words, they find no evidence of financial frictions which would prevent firms from adjusting the level of their nominal expenditures, as seemed to be the case for the US economy. Also in contrast with the limited participation hypothesis, households are found to adjust their portfolios relatively quickly in Italy, switching from deposits and shares to securities. Finally, consistent with the slowdown in economic activity induced by the interest rate hike, with automatic stabilizers at work on one hand and lower tax receipts on the other, the public sectors deficit increases after the shock.

Except for the above mentioned cases, the literature did not pursue further this research line and, to our knowledge, no evidence is available for the flow of funds of other countries, nor for the euro area as a whole. ${ }^{2}$ Why this? Once

\footnotetext{
${ }^{1}$ Throughout the paper we will refer to firms and non-financial corporations indifferently.

${ }^{2}$ In a recent contribution, Gameiro and Sousa (2010) have applied the same methodology to the Portuguese economy.
} 
agreed that these aspects are worth investigating both for the transmission of monetary policy and for macro-prudential purposes, the main reason for this gap in the literature is probably the lack of sufficiently long and disaggregated time series which could allow replicating the "flow of funds-in-a-VAR" analysis (the UK is a significant exception). ${ }^{3}$

This paper extends Christiano et al. (1996) and Bonci and Columba (2008) kind of analysis to the euro area economy as a whole. The flow of funds are used in order to gauge new insights into the impact of monetary tightening on the financing (borrowing) and financial investment (lending) decisions of households, firms, the government sector and the foreign sector. A number of new stylized facts on the policy transmission in the euro area arise.

We proceed in two steps. First we estimate a VAR model for the euro area economy which allows us to identify movements in the short-term interest rate (chosen as the policy instrument) that can be labelled as monetary policy shocks. Our results for the main macroeconomic aggregates are consistent with the literature and are not affected by the empirical puzzles which can be found in part of it. The (benchmark) model estimated in the first step is then augmented with the flow-of-funds variables, adding them one at a time according to the marginal strategy, in order to evaluate their response to the identified monetary policy shocks.

To allow for comparability, our set of financial aggregates also includes those considered by Christiano et al. (1996) and Bonci and Columba (2008). For each economic sector we consider net funds raised (new debt issued net of new financial assets acquired) and some sector-specific assets and liabilities. In particular, we investigate the impact of monetary policy on the flow of credit granted to households and firms, in light of the importance of this variable in the context of the ECB monetary analysis.

The remainder of the paper is organized as follows. Section 2 provides a brief overview of the existing literature on VAR models of monetary policy impact in the euro area. In Section 3 we describe the benchmark model, identify monetary policy shocks in the euro area, and analyse their impact on the main macroeconomic variables together with some robustness checks. Section 4 extends the analysis to the flow-of-funds variables, providing some new interesting insights into the impact of a monetary policy shock on lending

\footnotetext{
${ }^{3}$ The Fed began to publish flow-of-funds statistics on a continuous basis already in the 50s, while their European parallel, the financial accounts of the euro area, are available only back to 1999. An additional explanation for this gap in the literature might be that flowof-funds accounts, though being an integral part of the National accounts, are historically devoted less attention compared to other economic aggregates. In general, both academics and professionals are indeed far more familiar with the "real economy" variables (GDP, consumption, investment, etc.), while it can even be the case that people are not confronted with the flow of funds at all during their economics studies. As a result, flow of funds are sometimes seen as a "difficult animal" left to statisticians and national accountants, who are generally more interested (as it should be, in fact) in methodological issues related to the proper definition and measurement of these variables rather than in their possible use in the context of complex econometric models.
} 
and borrowing across the economy; results are contrasted with the literature available for the US and for Italy. Section 5 concludes.

\section{Monetary policy transmission in the euro area}

A number of contributions attempted to assess the effect of monetary policy shocks into the economy employing vector auto-regression (VAR) models. Although most studies focus on the US economy, some important results are also available for the euro area as a whole. Among the latter, in this section we will focus on three papers which are particularly relevant for our analysis.

Monticelli and Tristani (1999) estimated a VAR model for the euro area employing a parsimonious specification including: real GDP, the short-term interest rate and the price index. The response of output to a monetary shock (a 10 basis points fall in the nominal interest rate) is hardly significant (0.4 per cent above the baseline at the peak, after 2 years), and prices show a non-significant and short-lived rise on impact.

Peersman and Smets (2003) estimated a VAR model to study the monetary transmission mechanism in the euro area over the period 1980-1998. Their vector of endogenous variables includes: real GDP, consumer prices, the shortterm interest rate (the Euribor rate) and the real effective exchange rate (in a second specification a monetary aggregate is also included). To take into account world demand and inflation, and to help solve the price puzzle, the authors also included an exogenous block in the model. The main results can be summarised as follows: after a contractionary monetary policy shock (a 30 basis points increase in the short-term interest rate), there is a fall of output, a moderate liquidity effect and an immediate reduction of credit to the private sector.

More recently, another contribution to the VAR literature on the euro area has been provided by Giannone et al. (2009). As opposed to the above parsimonious models, they estimated a large VAR on the euro area economy including 31 variables and 13 lags. Similarly to Peersman and Smets (2003), the Euribor is chosen as the policy instrument. Using a Cholesky identification scheme to identify innovations in the short-term interest rate, they find that, following an unexpected tightening, industrial production declines quite persistently, prices are hardly affected, and the monetary aggregate falls below the baseline. Giannone et al. (2009) also provide a number of other interesting results, some of which will be recalled later on, to be contrasted with our findings.

All in all, despite the magnitude (and the sign) of the estimated monetary policy shocks varies across the literature according to the different model specification and to the different samples used, existing evidence on the monetary transmission in the euro area is in line with widely accepted theoretical priors and also similar, in many respects, to that available for the US economy. These findings suggest that a monetary tightening should result in higher short-term 
interest rates, a deceleration of money and credit, weaker economic activity, and a delayed and prolonged decrease in the price level.

\section{The benchmark VAR model}

In this section we present the model and identify the monetary policy shocks for the euro area economy. Our main results are contrasted with existing evidence, especially Peersman and Smets (2003). The identification of monetary policy shocks is not straightforward given that, as it has been broadly suggested in the literature, actual economic patterns are the result of the combination of two forces at work: they reflect the action of the policy maker, but they also depend on the state of the economy, i.e. on the development of the variables to which the central bank responds according to its strategy and its objectives. These two driving forces need to be disentangled in order to detect the effects of the policy interventions. In other words, we need to identify the exogenous non-feedback rule component of monetary policy. To this aim, some identifying assumptions are needed mainly as regards the choice of the policy instrument and the form of its interaction with the other endogenous variables. We will discuss our choices as to these issues in the present section.

We begin by estimating a standard vector auto-regressive (VAR) model of order $k$ like the following: $Y_{t}=A(L) Y_{t-1}+\epsilon_{t}$. We include four endogenous variables $(k=4)$ in the VAR:

$$
Y_{t}=\left(y_{t}, p_{t}, \text { pcom }_{t}, \text { int }_{t}\right)
$$

where $y$ is a measure of economic activity (real GDP), $p$ is the consumer price index, pcom is the world commodity price index, and int is a short-term interest rate (the EONIA rate). All variables are in log-levels and seasonally adjusted, except for the interest rate, which is in levels.

The sample is quarterly and spans from 1999Q1 to 2009Q2. This choice, besides being forced by the euro area flow-of-funds series' availability, is also supported by Weber et al. (2009) who suggest that, as a result of the transition to EMU, there might be a structural break in 1996-1998 in the log-level specification of a standard VAR model for the euro area. As a consequence, an analysis of monetary transmission in the euro area should be better based on a sample period starting after those years. The VAR endogenous variables are plotted in Figure 1; the recent financial turmoil shows up clearly especially in the drop of output and of the interest rate.

Although a number of earlier studies on the euro area economy, including Peersman and Smets (2003), have used the three-month Euribor as the policy instrument, we think the EONIA rate provides a better proxy for the monetary policy operating instrument over our sample period, especially during the onset of the financial crisis at the end of 2008. We also include a commodity price index as a proxy for expected inflation in the policy maker's information set, 
given that expected price developments are also relevant for the conduct of monetary policy in the euro area.

Monetary policy shocks are identified via a standard Cholesky decomposition, with variables ordered from the most exogenous to the most endogenous as in Equation 1. This identification scheme implies that monetary policy shocks can have only lagged impact on the other variables included in the model; at the same time, we assume that quarterly information on output, domestic and commodity prices is available to the policy maker within the same quarter.

Standard likelihood-ratio tests are used to determine the lag order of the VAR: results according to the most widely used criteria point to one lag as the most appropriate choice (see Table 1, in the Appendix). Despite the small number of lags, fitted residuals show no sign of autocorrelation (see Table 2); this result is quite relevant because the small sample size makes the degreesof-freedom issue potentially severe in the present study. The hypothesis of normality is also not rejected, both at the individual series level and jointly, at the 95 per cent confidence level (Jarque-Beras test results are reported in Table 3).

The log-level transformation used for the VAR variables allows for implicit co-integration in the data. We chose to avoid explicit co-integration analysis in the present analysis, in line with much of the literature on the empirical approach to modelling the effects of unexpected monetary tightening (including Peersman and Smets (2003) and Giannone et al. (2009), for the euro area); moreover, as underlined by Sims, Stock and Watson (1990), standard asymptotic tests are still valid if the VAR is estimated in levels, even if the variables are co-integrated.

Estimated policy shocks based on the above specification are displayed in Figure 2. In order to smooth the series and for ease of interpretation, we report the three-quarter centred moving averages of estimated residuals in the interest rate equation, as shocks are by construction serially uncorrelated and thus they tend to be noisy. As usual, one might think of monetary policy being "tight" when the smoothed policy shock is positive and "loose" otherwise. Conditional on our model specification, estimated policy shocks signal that monetary policy was relatively tight in 2008, at the onset of the global financial crisis; in interpreting this outcome one should keep in mind that a sharp increase in risk premia occurred during that period, thus impinging temporarily the ability of the policy maker to control money-market interest rates via standard measures. In this respect, the estimated stance would look even tighter had we used the Euribor rate instead of the EONIA as the policy interest rate. 


\subsection{The impact of a monetary policy shock on the economy}

The response of the VAR variables to a monetary policy shock, i.e. a 24-basis points (equal to one standard deviation) increase of the short-term interest rate $(i n t)$, is in line both with theoretical prior and with existing evidence on the euro area economy (IFRs are plotted in Figure 3).

Output $(y)$ begins to fall immediately after the tightening; the maximum response is a fall below the baseline by 60 basis points, occurring one year later. The response of prices $(p)$ is more delayed, but also more persistent. Prices fall only at the end of the first year after the shock and return to the baseline gradually. There is no sign of the price puzzle, i.e. the finding of a price increase following a tightening, which can be found in some of the VAR literature on the monetary policy transmission, also for the euro area (see, for example, den Haan et al. (2007), Eichenbaum (1992) and Sims (1992)).

The commodity price index (pcom) decreases during the first year after the shock. Given that developments in the euro area economy are likely to have only limited impact on the world demand for commodities, the response of this variable is most likely to be explained in terms of the co-movements between the level of economic activity in the euro area and in other large economies (e.g. the US economy).

We decided not to include an exchange measure in the model in order to keep our specification as parsimonious as possible and given that the euro area can be considered a relatively closed economy. Contrarily to Peersman and Smets (2003), we attain a reasonable identification of the monetary policy shocks (with no price puzzle, as we said) also without the exchange rate. Moreover, developments in the world demand and inflation are implicitly taken into account in the model through the commodity price index.

All in all, both the timing and the shape of te response of output are similar, in qualitative terms, to the literature available for the euro area; at the same time we find, for a given size of the shock, a larger fall of the level of economic activity.

\subsection{Robustness analysis}

In this section we present the results of some robustness checks performed in order to further validate the identification of monetary policy shocks. Taking the model presented above as a benchmark, we show that results as to the impact of an interest rate tightening on the economy remain broadly unchanged across some alternative model specifications.

For the first extension we include the real effective exchange rate in the information set of the policy maker. In a further specification, also in line with part of the VAR literature on the euro area, we include a broad money aggregate, namely M3, among the VAR endogenous variables. Given the recursive identification scheme, placing money after the interest rate means that the policy maker looks only at lagged values of the monetary aggregate in setting 
its instrument. In turn, this can be seen as a proxy for the fact that it is more medium-term monetary developments that matter in the ECB strategy, rather than responding to the latest short-term development in M3.

Two further variants involve the commodity price index: in the former this variable is not included in the model, similarly to what is done in Monticelli and Tristani (1999); in the latter, the world price index is treated as an exogenous variable, implying that it is part of the information set of the policy maker but it does not respond to monetary policy.

In terms of the above notation, four alternative specifications are compared with the (benchmark) Model $1, Y_{1}=(y, p, p c o m, i n t)$, namely:

$$
\begin{aligned}
& Y_{2}=(y, p, \text { pcom, exr }, \text { int }) \\
& Y_{3}=(y, p, \text { pcom, int }, m) \\
& Y_{4}=(y, p, \text { int }) \\
& Y_{5}=(y, p, \text { int }) \text { with } p c o m \text { exogenous }
\end{aligned}
$$

where $y$ is output, $p$ is the consumer price index, pcom is the commodity price index, int is the short-term rate, exr is the exchange rate, and $m$ is a broad monetary aggregate.

Estimated monetary policy shocks according to the model specifications 1 to 5 are plotted in Figure 4. There is a high correlation between the series: 0,97 between Model 1 and Model 2, 0.81 with Model 3, 0.77 with Model 4, and 0.68 with Model 5. From Figure 4 it arises that the biggest differences with respect to Model 1 are those obtained in the case of Model 4, i.e. that where the commodity price index is not taken into account. This holds true especially over the periods 1999-2000 and 2003-2005, when excluding the variable pcom from the policy maker's information set results in a tighter monetary policy. In those years the commodity price index experienced a fast growth (see Figure 1), so that the development of this variable is indeed likely to have played a significant role in the evaluation of the monetary policy stance by the policy maker.

Also the responses of output, prices, and the interest rate (which are common to all models) are fairly similar across the different specifications, both from the qualitative and the quantitative point of view (Figure 5).

The response of the exchange rate, in Model 2, turns out to be nonsignificant (Figure 5). Nevertheless, we are more interested in to what extent this variable affects the response of output and prices once it is added to the benchmark VAR: Figure 5 shows that such differences are negligible.

In line with the expected liquidity effect, and consistent with the literature on the money demand in the euro area (see Fase and Winder (1993) and Giannone et al. (2009) among others), in Model 3 the broad monetary aggregate declines after the shock. In other words, our framework is not affected by the liquidity puzzle, occurring when an interest rate tightening is associated with an increase in the broad monetary aggregate (see, for example, Reichenstein 
(1987), and Leeper and Gordon (1991)).

All in all, the above results support the choice of the benchmark VAR specification as in Model 1, especially in the light of the degrees-of-freedom issue mentioned above. The response of the main economic aggregates to a monetary policy tightening is robust across the alternative model specifications taken into account. Besides, and more importantly, they are in line with most of the VAR literature on the euro area, also with those studies using a much larger dataset and a wider sample period, like Giannone et al. (2009). In other words, we think that the above results support the view that the loss of information associated with the parsimonious benchmark VAR model is acceptable given the gain in degrees of freedom.

\subsection{The effect of monetary policy shocks on other macro vari- ables}

In order to further support the identification achieved, we examine the responses to a monetary policy tightening of a set of key macroeconomic aggregates which were not included in the benchmark model. This is done by including each variable in turn within the VAR variables, placing it in the last position (i.e. considering it as the most endogenous). IRFs obtained from these extended models are reported in Figure 6.

Both households' consumption and capital accumulation decline immediately after the monetary tightening. In line with existing evidence on the euro area economy (e.g. Peersman and Smets (2003)), the response of investment is much stronger (150 versus 24 basis points, respectively, at the peak) and drives output dynamic to a large extent.

Unemployment increases as of the second year after the shock, with a similar timing but a weaker response compared to output. This behaviour results in a pro-cyclical pattern of labour productivity (Figure 6), also in line with existing evidence on the euro area economy (see Peersman and Smets (2003)). The (weak) response of wages is consistent with the fall of production and the rise in unemployment. Taken together, the response of wages and that of productivity result in a unit labour cost increase at least during the first two years after the policy contraction.

In line with the expectations hypothesis of the term structure of interest rates, the impact of a 24 basis point increase in the policy rate on the longterm rate (the 10-year government bond yield) is rather limited; this is also consistent with the empirical evidence provided by Giannone et al. (2009), who find that the term-spread in the euro area decreases on impact after a monetary tightening.

Stock prices fall immediately after the interest hike, reaching the maximum impact about one year after the shock. This result is similar to that in Peersman and Smets (2003) and in Giannone et al. (2009). Also house prices decline after the shock, but the response is less pronounced and takes more to 
unfold $(-0,3$ per cent at the peak, versus -4 per cent observed in the case of shares, two years after the shock).

All in all, the shape and the magnitude of the responses of the additional macroeconomic variables taken into account confirm the appropriateness of the identification achieved with the benchmark Model 1.

\section{Monetary policy and the flow of funds}

In this section we provide a brief overview of the flow-of-funds statistics, before adding them to the benchmark VAR model in order to assess the response of lending and borrowing by all the sectors of the economy in the aftermath of a monetary policy shock in the euro area.

\subsection{The euro area flow of funds}

The flow-of-funds statistics show the financial assets and liabilities of all economic sectors (households, non-financial firms, financial corporations, the general government, and the foreign sector), both those already accumulated in the form of outstanding amounts of wealth (assets) or debt (liabilities) and the transactions occurring in the form of the different financial instruments (mainly deposits, securities, and loans). In the present study we focus on the transactions, i.e. on new financial assets acquired or financial liabilities issued in each period by the different sectors.

Aggregate flow-of-funds series for the euro area are being published by the ECB with a lag of about 4 months (which is currently being shortened to about 3 months). Quarterly series are available back to 1999. They result from the aggregation of harmonised national data compiled according to the methodological standards set in the European System of National Accounts (ESA95). European flow of funds (also referred to as the financial accounts) are published on a non-consolidated basis, meaning that intra-sectoral transactions are not netted out; this is the case, for example, of securities issued by banks and bought by other banks, or inter-company loans. Moreover, published series are at current prices and are not seasonally adjusted.

In line with Christiano et al. (1996) and Bonci and Columba (2008) we focus on net funds raised by the sectors, defined as the difference between the net incurrence of liabilities and the net acquisition of financial assets. A positive (negative) value of net funds raised means that the sector is a net borrower (net lender) of funds vis-à-vis the rest of the economy, including the foreign sector.

Figure 7 shows net funds raised by each sector in the euro area from 1999Q1 to 2009Q2. All series were deflated using the GDP price deflator and corrected for seasonality, if present in the data.

As it is well known for the euro area economy, households are net lenders over the whole sample period; from the end of 2001 onwards their financial 
saving (the excess of disposable income over consumption and housing investment) has increased; in other words, households have been lending more and more to the rest of the economy. Firms, on the other hand, have been net borrower of funds (36 billions of euros, on average, per quarter), meaning that the sources of internal financing (i.e. undistributed earnings), have been generally too small to finance business investment.

As regards the other sectors of the economy, net funds raised by financial corporations show a high volatility around a relatively small average (-13 billion of euros). The chart for the general government shows the growth in the budget deficit (although its definition is not perfectly equivalent to our measure of net funds raised) in 2000-2003 and its reduction from 2004 onwards. The euro area as a whole has been slightly net lender vis-à-vis foreign residents over the sample (some 5 billions of euros, on average). Finally, as was the case for financial corporations, net foreign inflows into the euro area are highly volatile, making the interpretation of these variables somewhat tricky.

Figure 7 shows a drop in households' net borrowing (i.e. an increase of funds lent by households, net of new debt taken) in the aftermath of the financial crisis, mirrored by a huge increase in the amount of funds raised by the government sector, also due to the massive securities issuance needed to finance the banking system bailouts and the fiscal stimulus interventions in some countries.

\subsection{Borrowing and lending after a policy tightening}

In this section we analyse the response of the euro area flow-of-funds variables to an unexpected monetary policy tightening. For the sake of comparability with the existing literature, namely Christiano et al. (1996) for the US and Bonci and Columba (2008) for Italy, we focus on net funds raised by all sectors but also, in the case of households and firms, on some additional categories of financial assets and liabilities. This is achieved adding one variable at a time to the benchmark VAR specification, placing it in the last position, i.e. considering it as the most endogenous in the model.

As Christiano et al. (1996) pointed out, while this procedure, also referred to as marginal strategy, deals with the problem of parameter profligacy, it has one potentially relevant drawback. Because estimated innovations to the interest rate equation can depend, in principle, also on the lagged values of the variable being included in the VAR, the estimated policy shocks might differ across the various specifications, introducing an important source of bias in the results. To address this issue, we compared monetary policy shocks estimated under the benchmark VAR with those resulting from the most relevant flowof-funds augmented models. Results are reported in Figure 8: our policy shocks estimates are very similar across the various specifications, supporting the comparability of the results obtained for the different financial variables at study. 
In the next sections we will go through the various sectors of the economy to analyse to what extent their borrowing (issuance of liabilities) and lending (acquisition financial assets) activity is affected by monetary policy shocks. We will focus particularly on the non-financial private sector, i.e. firms and households.

Firms. The response of net funds raised by non-financial corporations after the interest rate hike (an increase by 24 basis points) is never significant (Figure 9). Nevertheless, looking at the individual effect on the asset and on the liability side, some interesting results arise.

In line with standard monetary business cycle models, in the aftermath of the tightening both firms' financial assets and liabilities decrease significantly, before returning to the baseline about one year after the shock; the response of liabilities is stronger in quantitative terms and also somewhat more persistent (Figure 10). Taking into account also the fall of firms' capital formation, occurring over the same quarters (Figure 6), this outcome provides evidence in favour of firms' ability to cut on their level of nominal expenditures after the policy tightening and the induced drop in sales and profits. The reduced issuance of new debt by firms is also consistent with both the money view (standard IS/LM models) and with the credit view of the transmission mechanisms of monetary policy (e.g. Bernanke and Blinder (1988)) and also with monetary business cycle models (Fuerst (1994)).

Shortly after the monetary policy shock, firms meet (at least part of) their financing needs relying on their liquid assets: in fact, the decrease of firms' liabilities is mirrored by a reduction of their deposits holding (Figure 10). Part of the literature (for example, Almeida, Campello and Weisbach (2004) and Han and Qiu (2007) for the US; Pàl and Ferrando (2010) for the euro area economy) has attempted at interpreting the sensitivity of firms' demand for liquid assets to cash flow as a sign of difficulties in accessing external finance. Cash holding of small firms is generally found to be more sensitive to cash flow than in the case of large corporations; this is often taken as evidence in favour of firms' motivation to increase precautionary saving to provide for future investment needs, which might be especially necessary for small firms because they tend to be more financially constrained. In this context, our results based on the augmented VAR methodology would seem to point to the fact that this precautionary-cash-holdings effect, if present, is not dominant in the case of euro area firms.

Firms seem to use part of the liquidity also to provide funds to other firms, mainly in the form of inter-company loans (in fact, loans granted are found to increase after the shock), probably also as a consequence of the higher cost of external funds (they reduce the net issuance of loans from other sectors and of securities) due to the restrictive policy shock. Finally, the response of trade credits, although negligible in statistical terms, parallels the slowdown of economic activity induced by interest rate hike. 
The modest response of firms' net borrowing contrasts with the US evidence provided by Christiano et al. (1996), who find an increase of net borrowing after the policy shock, mainly due to the increase of short-term liabilities issued by firms (especially large corporations). Christiano et al. (1996) take this outcome as evidence of financial frictions, due to contracts in place, which would prevent firms from adjusting immediately their level of inventories to the new (lower) level of demand. On the other hand, our results are similar to those found by Bonci and Columba (2008) for the Italian economy.

Taken together, the response of net funds raised by the business sector hints at some interesting differences among the structural differences between these economic systems. Firms' net borrowing depends crucially on their ability to cut on expenditures (for instance investment) and reduce their need for external financing after the policy shock. In this context, the finding that US firms would face higher cost inertia than in the euro area (and in Italy), might be related to the average firm size which, in turn, could affect the possibility for firms to alter their current expenditures promptly against the new economic juncture.

But besides this feature, which affects credit demand, credit supply factors might also play a relevant role in accounting for firms' issuance of liabilities in the aftermath of the tightening. First of all, given that to cut quickly on investment plans or on the level of expenditures comes necessarily at a cost, firms' decision to do so could also depend significantly on the impact of interest rate hike on their overall credit conditions (the higher the increase in the cost of credit for firms, the higher the opportunity cost of continuing pre-determined investment plans in the face of reduced profits). Second, the response of firms' issuance of new liabilities after the tightening might reflect to a significant extent also banks' decision to reduce the availability of loans to the business sector as a consequence of a sudden rise in their risk aversion or in the cost of funding, or to manage worsening liquidity conditions. In this respect, there is widespread evidence supporting capital market imperfection theories, according to which larger firms are less subject to risks of credit crunch compared to small ones, because they are less prone to asymmetric information problems (see Christiano et al. (1996), Gertler and Gilchrist (1993, 1994), and Ehrmann (2000)); this implies that a policy-induced decrease of credit supply affects large companies less than small firms; given that the former are more common in the US than in the euro area, this might explain our result as to net funds raised by the business sector after a monetary policy shock.

Households. Some interesting evidence on the impact of a monetary policy restriction on borrowing and lending by the household sector can be derived from the impulse response function of net funds raised (Figure 9) and of the major categories of financial assets and liabilities (Figure 11). In this section we will distinguish between the short-run response (changes occurring within the first year) and the medium-term behaviour of the household sector. 
Households' net borrowing decreases in the short run after the interest rate hike. In other words, in the quarters immediately following the tightening households lend more funds (in net terms) to the rest of the economy than they would do in normal times. This could be explained in terms of households' incentive to increase precautionary saving (reducing consumption), in the light of the deteriorated economic perspectives associated with the rise of unemployment induced by the policy tightening (as shown in Figure 6).

Our result parallels the finding of Bonci and Columba (2008), who observe a decline of net funds borrowed by Italian households in the first year after the shock: in the case of Italy, though, the strongest impact is on the asset side, while we find euro area households to respond to the interest hike mainly reducing their debt issuance (Figure 11): at the peak the decrease amounts to more than 4 billions of euros, corresponding to almost 7 per cent of the corresponding average quarterly flow (Table 4). The response of households' net borrowing was less clear in Christiano et al. (1996), who conclude that for the US economy "there is little evidence against the view that net funds raised by the household sector initially remain unchanged" after a tightening.

After the initial decline, households' net borrowing starts recovering during the second year after the shock (Figure 9), mainly as a result of the higher debt issuance (Figure 11). The medium-term deterioration of households' net financial position, although of limited statistical significance, unveils a few interesting features about the impact of monetary policy on this sector. First of all, the timing of the pick up of households' net borrowing coincides with the recovery of economic activity and, more importantly, of private consumption (Figure 6).

On the asset side, even though the overall response is not significant in statistical terms, looking at the individual instruments some notable features arise as to the medium-term impact of monetary policy. For instance, we find evidence of a re-composition of households' portfolio, with a reduction of liquidity (currency and deposits) and an increase in the accumulation of shares. The former might be ascribed to the increase of the opportunity cost of holding deposits, conceding that, in general, the impact of an increase in the policy rate on the deposit rate is partial and delayed. Households would then have an incentive to draw on bank deposits to finance part of their growing consumption in the context of the slowdown of disposable income; the remaining part would be financed by issuing new debt, which is indeed also found to pick up at the same time, i.e. between two and three years after the shock (Figure 11).

The observed medium-term increase in the accumulation of quoted shares (some 16 per cent of the average flow at the peak; Table 4) can be associated with the observed rapid decrease in stock prices induced by the monetary policy shock (Figure 6): one year after the shock, households might be willing to increase their investment in quoted shares (and mutual fund shares) because they are considered cheap enough to off-set the fall of firms' expected future 
profitability.

All in all, our results hint at households reacting to the policy tightening in the short run mostly by reducing the issuance of liabilities (resulting in a reduction of net funds raised from the rest of the economy), while there are signs of a re-composition of households' financial portfolio from bank deposits to shares in the medium term.

The other sectors of the economy. In this section we comment briefly the impact of a monetary policy shock on the borrowing and lending decisions of the general government, financial corporations and the foreign sector.

The decrease of net funds raised by households (and also by firms, although with little statistical significance) in the aftermath of a policy restriction is mirrored by an increase of net borrowing by the public sector (Figure 9). The observed increase of the public deficit after the shock is quite significant if one takes into account that over the first two years the cumulated gap with respect to the baseline amounts to more than 33 billions of euros, just as the average of the quarterly flow series. This result is consistent with the expected budget worsening due to lower tax receipts following the slowdown in economic activity induced by the interest rate hike and with the cost of automatic stabilizers. Indeed, the timing of the observed increase in the euro area budget deficit follows quite closely the decrease of output and that of employment (Figure 6).

Our finding for the euro area government also parallels the evidence provided by Bonci and Columba (2008) for the Italian economy. On the other hand, Christiano et al. (1996) tried to explain the (counter-intuitive) fall in public deficit observed for the US economy after a policy tightening in terms of a temporary increase in personal tax receipts which would vanish only in the following quarters, as the economic slowdown gains momentum.

Net funds raised by the financial sector (banks, insurance companies and other financial intermediaries) increase at impact after the shock (Figure 9). The response of net borrowing is rather limited and short-lived and the interpretation of the result is somewhat impaired by the relatively small and highly volatile net financial flows involving this sector (for which financial assets tend to be akin to liabilities). Nevertheless, it is interesting to note that despite the overall net impact on borrowing is rather limited, both assets and liabilities of financial corporations decelerate significantly after the tightening (Figure 12). Taking into account that about 40 per cent of the sector's financial assets represent loans granted to the rest of the economy, the relevance of this result becomes quite clear (loan development in the aftermath of a monetary policy shock will be discussed more in detail in the next section).

Finally, net borrowing by the foreign sector, which is anyway quite erratic due to the small amount of the flows, is hardly affected by the tightening (Figure 9). 


\subsection{The response of credit growth}

In this section we focus on the impact of monetary policy on credit development, investigating the response of loans granted to the non-financial private sector (households and firms) after an unexpected interest rate hike by the policy maker. Private sector loan growth is of special interest in the euro area, given its prominent role in the ECB assessment of monetary developments in the context of its monetary policy strategy (the "monetary pillar"); in fact, credit to the private sector is one of the main counterparts of monetary aggregates and, as such, is monitored as a potential source of inflation in the medium to long term.

After the interest rate increase (as usual, by one-standard deviation, equal to 24 basis points), loans granted to households and firms, net of reimbursements, decline quickly and quite persistently (Figure 13). The peak response is a decrease by some 12 billions of euros, corresponding to 8 per cent of the average quarterly flow, and occurs 3 quarters after the shock (Table 4); new loans granted go back to the baseline after two years. This result is consistent with the lower demand for loans induced by the slowdown of economic activity (less consumption, less investment, less working capital financing needs, etc.) and with the tighter credit standards which are generally applied by banks (higher cost of credit, more collateral, etc.), as the credit channel of monetary policy would predict. It is also in line with existing evidence on the euro area economy provided by Peersman and Smets (2003), who observe a quick and persistent decline of loans after a policy tightening.

The negative response of loans to the private sector is driven mainly by business loans (almost 9 billions decrease, 9 per cent of the average). The drop in loans to households is smaller (about 2 billions, some 4 per cent of the average) and is accounted for especially by the deceleration of loans for house purchase (by more than 10 per cent below the baseline). The response of consumer credit, on the other hand, though statistically significant is of a negligible magnitude. These results are in line with existing evidence for the US and for the euro area (Gertler and Gilchrist (1993) and Giannone et al. (2009), respectively).

In line with the small change in the long-term interest rate which is associated with the policy tightening (as seen in Figure 6), it is mainly short-term loans that fall after shock (by more than 20 per cent of the average flow one year after the shock; Table 4), while the response of long-term loans is hardly significant (Figure 13); looking at the individual sector level, this result holds true for both households and firms.

Although banks provide the greater part of loans to the business sector in the euro area, a relevant share of loans (especially long-term) are also granted to firms by other agents, such as other financial corporations, insurance companies and, as in the case of inter-company loans, also by other non-financial corporations. As regards households, non-bank loans are generally negligible 
over the sample, but their importance has increased substantially since the onset of the financial crisis (Figure 14).

Not surprisingly, the response of private sector loans to a monetary policy shock reflects, to a large extent, the dynamic of loans granted by banks (Figure 15). But focussing on the smaller component, i.e. loans granted by non-bank agents, an interesting result arises: the policy tightening is associated with a credit expansion occurring in the very first quarters. While the overall impact on such non-bank loans is significant only for households, the response of the long-term component turns out to be relevant both for households and for firms (Figure 16).

The response of long-term non-bank loans to firms is of particular interest, because they account for almost half of the total in the case of the business sector. After the 24-basis-point interest rate tightening, long-term loans to firms increase at impact by about 3 billions of euros, corresponding to some 12 per cent of the average of the quarterly flow (Table 4), supporting the view that firms try to substitute at least a fraction of bank loans with alternative sources of funds, including inter-company loans, after the change in the shortterm rate.

Also the response of long-term loans granted to households by sectors other than banks is considerable compared to the average of the series (some 16 per cent of the average flow at the peak; Table 4). This result might hint at some households, especially those whose loan application has been (or would probably be, given their weak financial situation) rejected by banks, attempting to borrow more funds from other financial institutions, possibly also being ready to pay a higher cost.

The increase of loans to the private sector in the aftermath of a tightening, despite it might be considered as counter-intuitive at a first glance, is not new in the empirical literature on the impact of monetary policy. A similar outcome, although referred to total loans (while in our case is only non-bank loans that are found to grow after the shock), was found for the US economy by Christiano et al. (1996), Bernanke and Gerlter (1995) and den Haan et al. (2007). Also for the euro area, Giannone et al. (2009) detected a positive and persistent response of (total) business loans after a monetary contraction.

A number of possible explanations have been put forward in the literature for the observed positive effect of an adverse monetary policy shock on lending; they involve both the demand and the supply side of credit. Some of these might also apply to our case, where it is only non-bank loans increasing after the tightening. First, when conditions on the trade credit market deteriorate, as it is normally the case in an economic downturn, firms might need more time for cashing their sales, thus increasing their working capital financing needs. On the other hand, to face rising unemployment and the cutback of financial wealth associated with the slowdown of asset prices (Figure 6), households might be willing to maintain a minimum level of consumption also increasing their demand for loans. Moreover, agents might react to the 
tightening drawing from pre-committed credit lines that are locked at the lower pre-shock rate, especially when the response of lending rates to the tightening is delayed. These factors could help accounting for the increase in loan demand in the aftermath of the policy shock.

As regards the supply side, Bernanke and Gertler (1995) argued that a credit expansion can still be consistent with a reduction in the supply of loans (which is what the bank lending channel would predict), provided that firms' demand for loans is actually higher that the observed equilibrium in that it is met by financial institutions only partially. A similar argument could be applied to the household sector.

\section{Conclusion}

This paper has investigated the transmission of monetary policy in the euro area via its impact on the borrowing and lending decisions of the economic sectors. An estimated VAR model is used to identify monetary policy shocks in the euro area. The model is not affected by any of the empirical puzzles which can be found in part of the literature and, despite the parsimonious specification, can account for the main stylized facts on the impact of monetary policy on the key macroeconomic aggregates. The interest rate tightening has a significant negative impact on output and employment, especially via the drop of investment; the fall of consumer prices below the baseline is more persistent and is associated with a quick drop in stock prices and with a modest but prolonged slowdown in the real estate price.

Augmenting the benchmark VAR model to include the flow-of-funds variables, a number of interesting results arise as to the transmission of monetary policy through the flow of funds lent and borrowed among the sectors as a result of their real imbalances. Results have also been confronted with existing empirical evidence based on the flow of funds, namely for the US and for the Italian economy. Differences, although partly due to the different sample periods or to the specific model specification taken into account, are useful in detecting the impact of structural differences (firm size, agents risk aversion, the development of financial markets, etc.), in the transmission mechanism of monetary policy.

Our main results as to the response of the flow-of-fund variables to a onestandard deviation increase of the short-term rate can be summarised as follows: firms cut on their issuance of liabilities and on their acquisition of financial assets, with a negligible overall effect on net funds borrowed from the rest of the economy. Consistent with standard monetary business cycle models, firms face the slowdown of profits and the higher cost of credit which follows the policy tightening by drawing on their liquidity and have more recourse to inter-company loans, as a (partial) substitute for bank loans.

All in all, based on the above results we find no evidence of significant financial frictions in the euro area which would prevent firms from adjusting 
their level of nominal expenditures after the policy shock, as is the case in the US economy according to Christiano et al. (1996). Besides firms' ability to adjust their nominal expenditures and reduce their financing needs, which affects credit demand, the observed drop in business loans after the policy shock might of course be related to a deterioration in the supply of loans (up to a credit crunch). In this respect, the different response found for the US economy by Christiano et al. (1996), that is, an increase of firms' net borrowing after the shock, could be due to the larger average firm size, assuming that large corporations are less subject to the worsening of business conditions and thus might manage to smooth the impact of reduced sales via larger debt issuance (instead of cutting on investment) more than small firms.

The euro area household sector reacts to the policy tightening by reducing the issuance of new financial liabilities rather quickly, resulting in an acceleration of (net) funds lent to other sectors. Together with the observed reduction of private consumption, this result could suggest that households try to increase precautionary savings in the context of the weak economic juncture, observing the fall of output and the rise of unemployment. Reverting from the short-term response, households start borrowing more funds (in net terms) from the rest of the economy two years after the shock, when the recovery of consumption also starts materialising. Besides financing their increasing levels of consumption (with disposable income still weak due to the relatively high unemployment), the rise of new liabilities issued is used by households, together with part of their liquid assets, to accumulate more shares, whose price has fallen significantly in the meantime.

We also analysed the impact of an interest rate hike on credit development, given the relevance of the latter in the conduct of monetary policy in the euro area, in the context of the monetary pillar of the ECB strategy. Consistent with the lower credit demand associated with the slowdown in economic activity and with the bank lending channel of monetary policy, the interest rate tightening is associated with a significant fall in total loans to the private sector, especially short-term; the result is confirmed when only bank loans are taken into account, while the impact on non-bank loans is of the opposite sign, especially for the household sectors.

All in all, the heterogeneity of the sectors' responses hints at the relevance of the analysis based on the flow-of-funds data for the conduct of monetary policy and calls for similar exercises to be developed also for other countries, taking advantage of the growing availability, improved timeliness and better quality of the flow-of-funds statistics worldwide. 


\section{References}

Almeida, H., M. Campiello and M. S. Weisbach (2004), "The cash flow sensitivity of cash", The Journal of Finance, Vol. LIX, 4.

Bernanke, B. S. and A. S. Blinder (1992), "The Federal Funds Rate and the Channels of Monetary Transmission", American Economic Review, 82(4), 90121.

Bernanke, B. S. and M. Gertler (1995), "Inside the Black Box: The Credit Channel of Monetary Policy Transmission", Journal of Economic Perspectives, $9(4), 2748$.

Bernanke, B. S. and A. S. Blinder (1988), "Credit, Money and Aggregate Demand", American Economic Review, 78(2), 435-439.

Bonci, R. and Columba, F. (2008), "Monetary policy effects: new evidence from the Italian flow of funds", Applied Economics, 40(21), 2803-2818.

Christiano, L., Eichenbaum M. and C. Evans (1994), "Identification and the Effects of a Monetary Policy Shock", in M. Blejer, Z. Eckstein, Z. Hercowitz and L. Leiderman (eds.), Financial Factors in Economic Stabilization and Growth, Cambridge University Press.

Christiano, L., Eichenbaum M. and C. Evans (1996), "The Effects of Monetary Policy Shocks: Evidence from the Flow of Funds", Reviews of Economics and Statistics, 78, 16-34.

Christiano, L., Eichenbaum M. and C. Evans (1997), "Sticky Price and Limited Participation Models: A Comparison", European Economic Review, 41(6), 1201-1249.

Christiano, L., Eichenbaum M. and C. Evans (1999), "Monetary policy shocks: What have we learned and to what end?", J. Taylor and M. Woodford (eds.), Handbook of Macroeconomics, North Holland.

Den Haan, W., Sumner, S. and G. Yamashiro (2007), "Bank loan portfolios and the monetary transmission mechanism", Journal of Monetary Economics, $54(3), 904924$.

Drudi, F. et al. (2007), "Corporate finance in the euro area", Task Force of the Monetary Policy Committee of the European System of Central Banks, ECB Occasional Paper Series, June, 63. 
Eichenbaum, M. (1992), "Comment on Interpreting The Macroeconomic Time Series Facts: The Effects of Monetary Policy", European Economic Review, 36(5), 1001-1011.

Ehrmann, M. (2000), "Firm Size and Monetary Policy Transmission. Evidence from German Business Survey Data", ECB Working Paper Series, 21.

Fase, M. and C. Winder (1993), "The demand for money in the Netherlands and the other EC countries", De Economist, 471-495.

Fuerst, T. (1994), "The Availability Doctrine, Journal of Monetary Economics, $34,429-444$.

Gameiro, I. M. and J. Sousa (2010), "Monetary Policy Effects: Evidence from the Portuguese Flow of Funds", Banco de Portugal Working Papers, 14.

Gertler, M. and S. Gilchrist (1993), "The Role of Credit Market Imperfections in the Monetary Transmission Mechanism: Arguments and Evidence", Scandinavian Journal of Economics, 95(1), 43-64.

Gertler, M. and S. Gilchrist (1994), "Monetary Policy, Business Cycles and the Behavior of Small Manufacturing Firms", Quarterly Journal of Economics, 109(2), 309-340.

Giannone, D., M. Lenza and L. Reichlin (2009), "Money, credit, monetary policy and the business cycle in the euro area". Paper presented at the conference "Monetary policy transmission mechanism in the euro area in its first ten years", mimeo, Frankfurt am Main, September, 28-29.

Han, S. and J. Qiu (2007), "Corporate precautionary cash holdings", Journal of Corporate Finance, 13, 43-57.

Leeper, E. and D. Gordon (1991), "In Search of the Liquidity Effect", Journal of Monetary Economics, 29, 341-69.

Monticelli, C. and O. Tristani (1999), "What does the single monetary policy do? A SVAR benchmark for the European Central Bank", ECB Working Paper Series, 2.

Pàl, R. and A. Ferrando (2010), "Financing constraints and firm cash policy in the euro area", The European Journal of Finance, 16(2), 153-171.

Peersman, G. and F. Smets (2003), "The monetary transmission mechanism in the euro area: evidence from VAR analysis", in Angeloni I., A. Kashyap and 
B. Mojon (eds) "Monetary policy transmission in the euro area", Cambridge University Press.

Reichenstein, W. (1987), "The Impact of Money on Short-term Interest Rates", Economic Inquiry, 25(11), 67-82.

Sims, C. (1980), "Macroeconomics and Reality", Econometrica, 48, 1-48.

Sims, C. (1992), "Interpreting the Macroeconomic Time Series Facts: The Effects of Monetary Policy", European Economic Review, 36(5), 975-1000.

Sims, C., Stock J. and M. Watson (1990), "Inference in linear time series models with some unit roots", Econometrica, 58(1), 113-144.

Sims, C. and T. Zha (1995), "Does Monetary Policy Generate Recessions?", manuscript, Yale University.

Weber, A., Gerke, R. and A. Worms (2009), "Has the monetary transmission process in the euro area changed? Evidence based on VAR estimates", BIS Working papers, 276. 


\section{Appendix - Figures and Tables}

Figure 1: VAR model variables
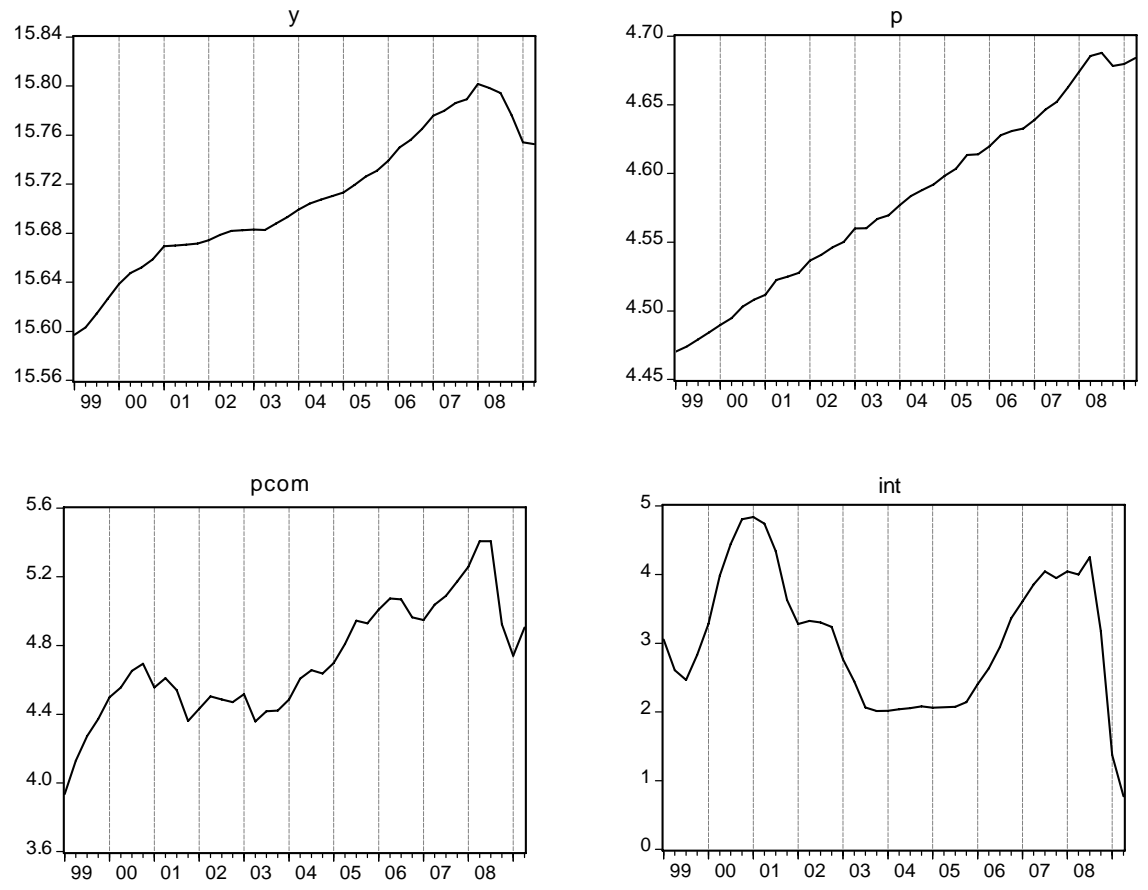

Note: $y$ is the $\log$ of real GDP, $p$ is the $\log$ of HICP, pcom is the log of world market prices of raw materials (expressed in euro and weighted according to commodity imports of OECD countries), int is the EONIA interest rate. All variables are in log-levels except for int, which is in levels. 
Figure 2: estimated monetary policy shocks (percent, three-quarter centred moving average)

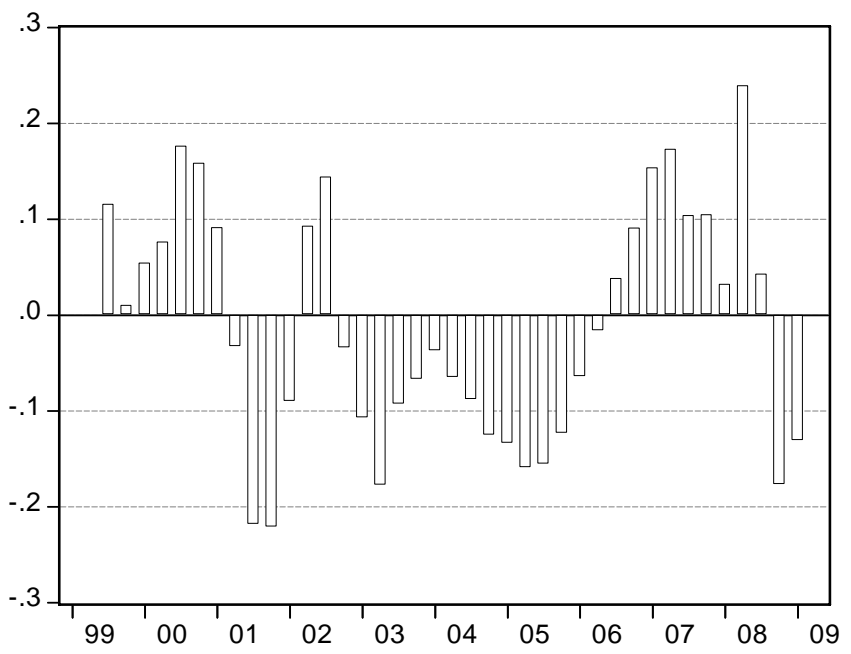

Figure 3: the impact of a contractionary monetary policy shock
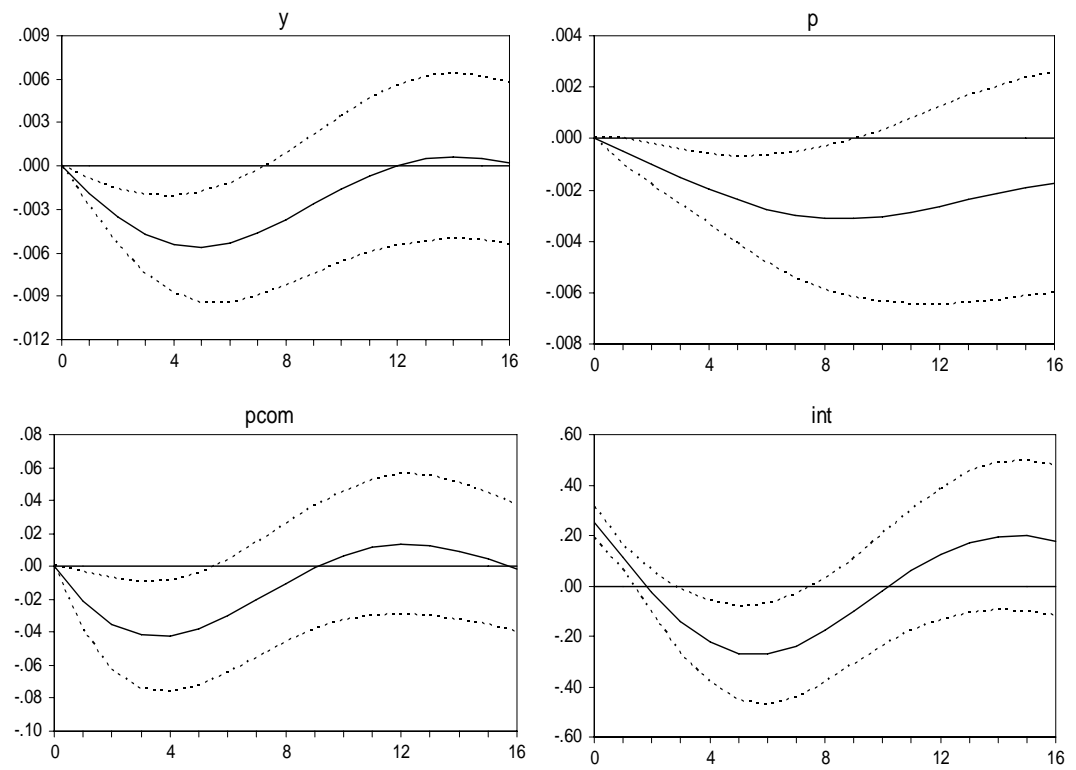

Note: deviations from baseline following a 24-basis point increase in the short-term interest rate. Dashed lines are \pm 2 standard error bands from 1000 Monte Carlo replications. 
Figure 4: comparing estimated policy shocks across alternative model specifications

(three-quarter centred moving average)

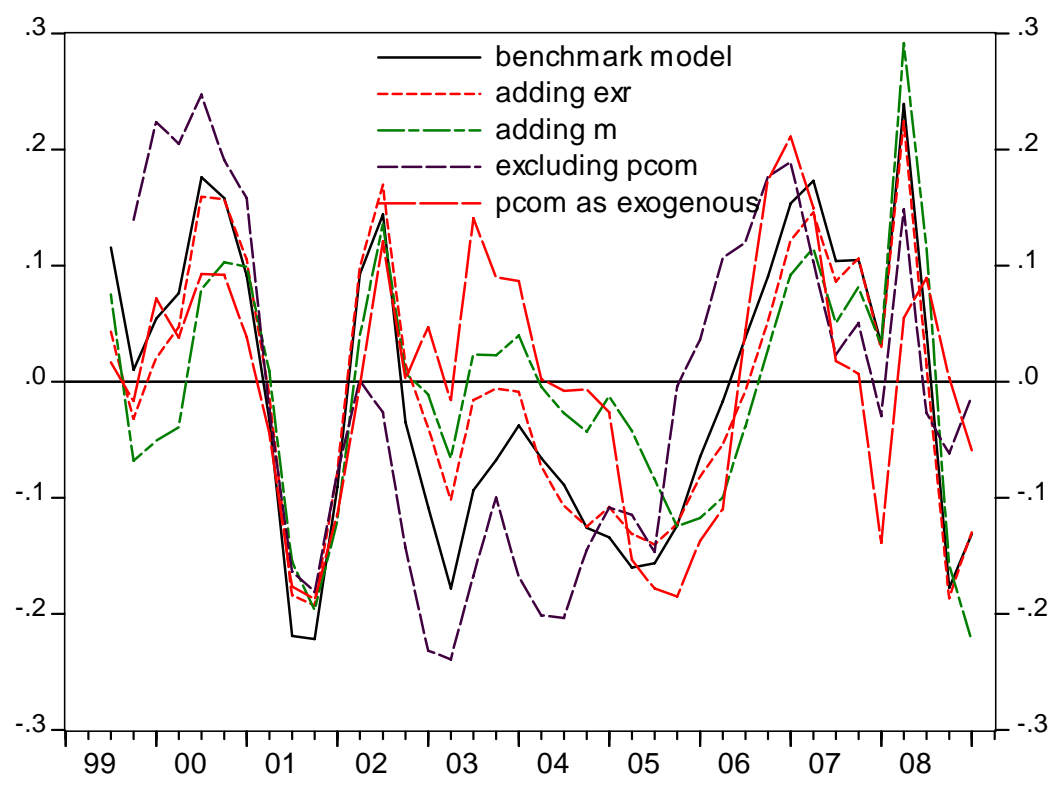


Figure 5: comparing impulse responses across alternative model specifications
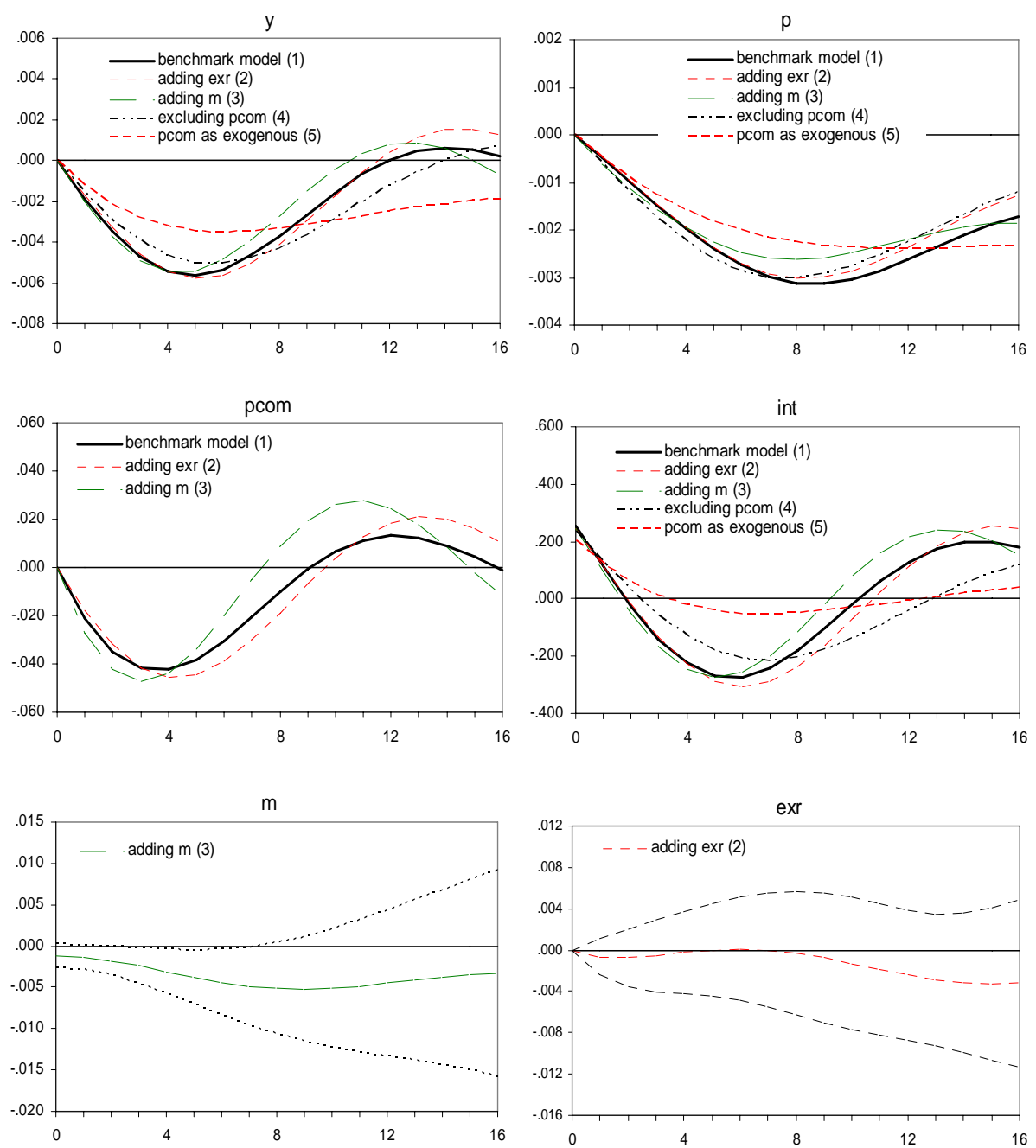

Note: deviations from baseline following a 24-basis point increase in the shortterm interest rate according to the various model specifications. For an easier interpretation, \pm 2 standard error bands from 1000 Monte Carlo replications are reported only for the IRFs of $m$ and exr. 
Figure 6: the effect of a contractionary monetary policy shock on other macro variables
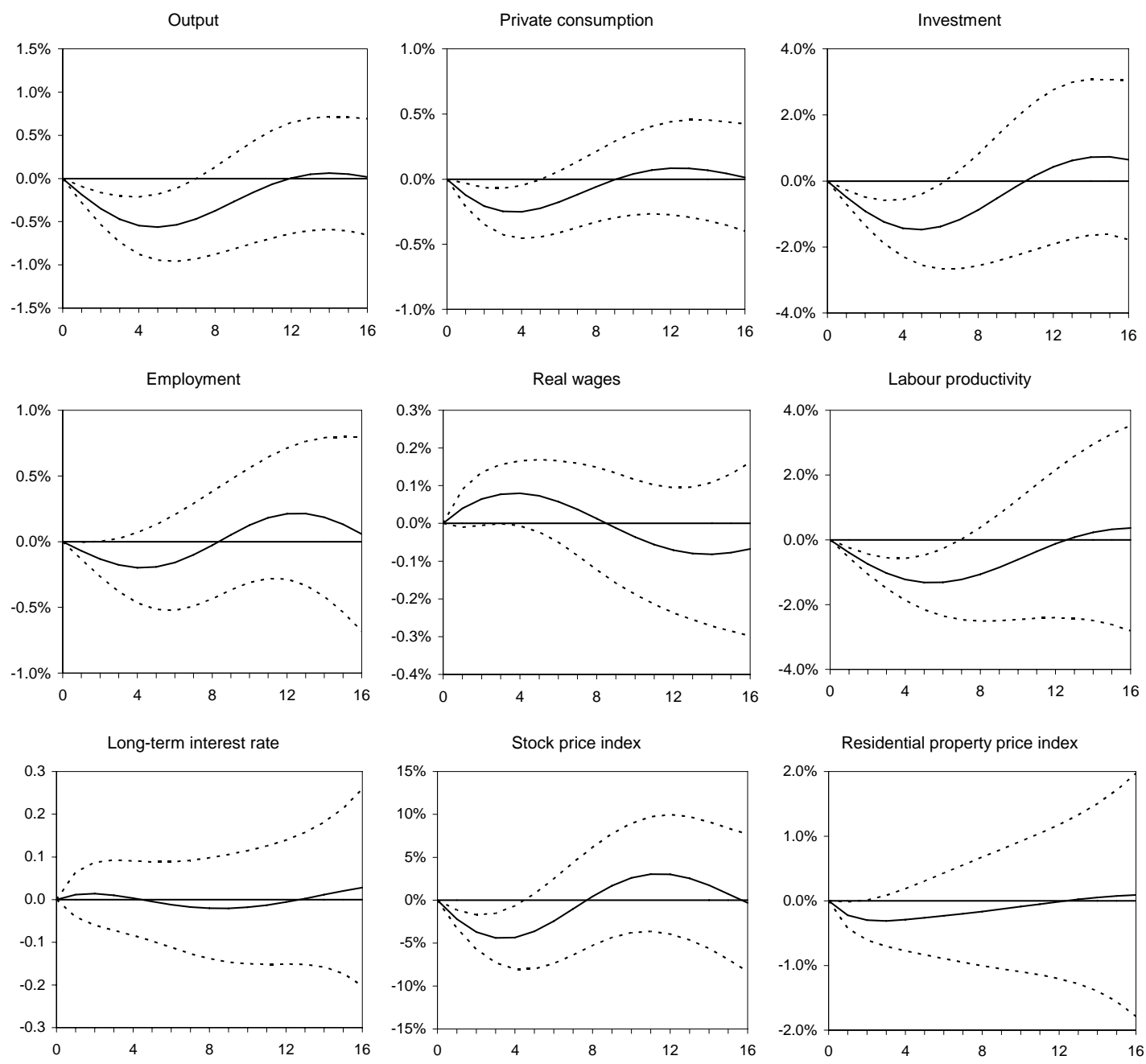

Note: percentage deviation from the baseline following an exogenous one standard deviation (24 basis points) increase in the short-term interest rate. Dashed lines are \pm 2 standard error bands taken from 1000 Monte Carlo replications. Each IRF has been estimated from a 5variable VAR in which each macro variable was added in turn to the benchmark model, placed in the last position. All variables are in log-level, at constant prices and adjusted for seasonality, when present. 
Figure 7: net funds raised by each sector (quarterly flows, seasonally adjusted; millions of 1995 EUR)
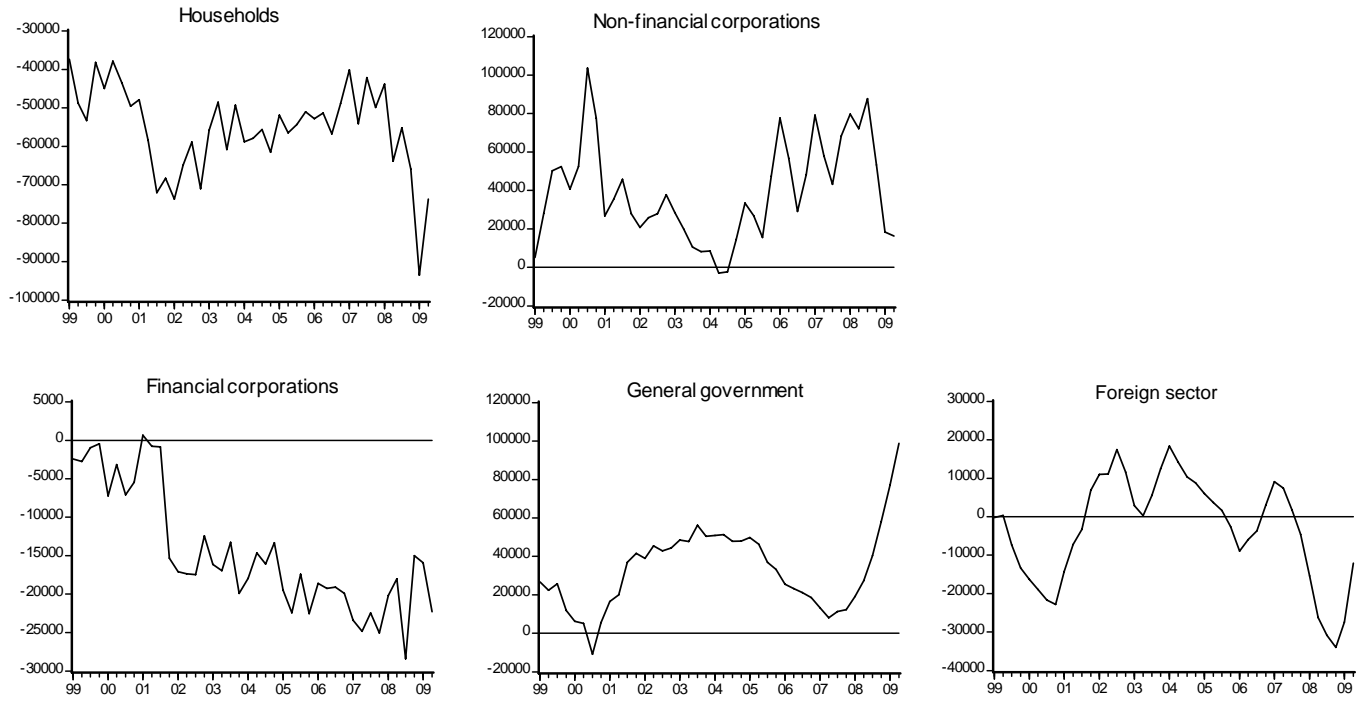

Figure 8: comparing estimated policy shocks across different flow-of-funds augmented models

(three quarter centred moving average)

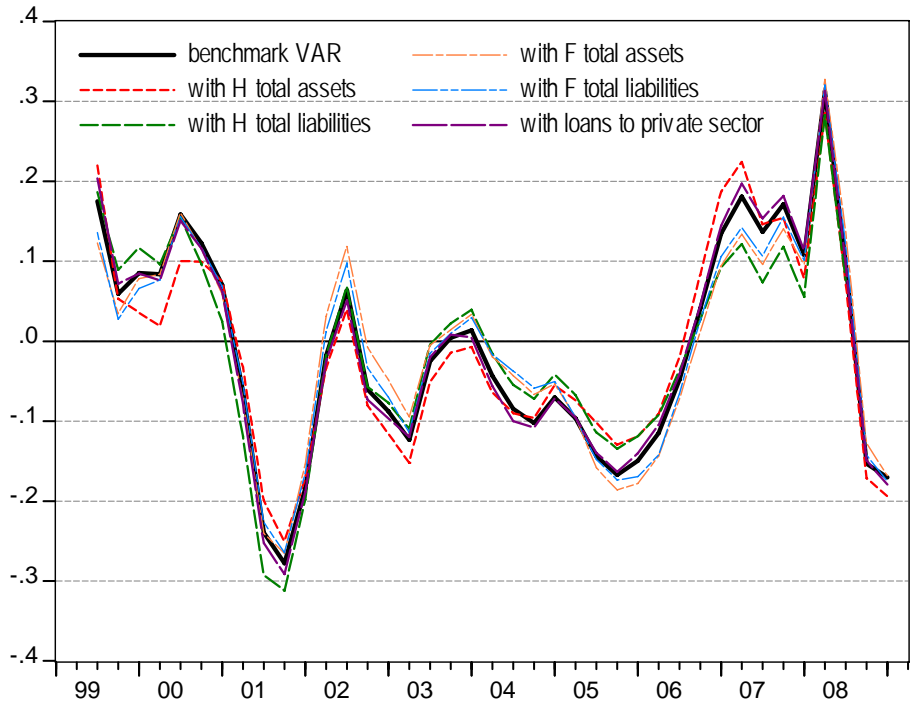

Note: $\mathrm{H}$ and $\mathrm{F}$ stand for households and non-financial corporations (firms), respectively. 
Figure 9: impact of a contractionary monetary policy shock on net funds raised (deviation from the baseline; millions of 1995 EUR)
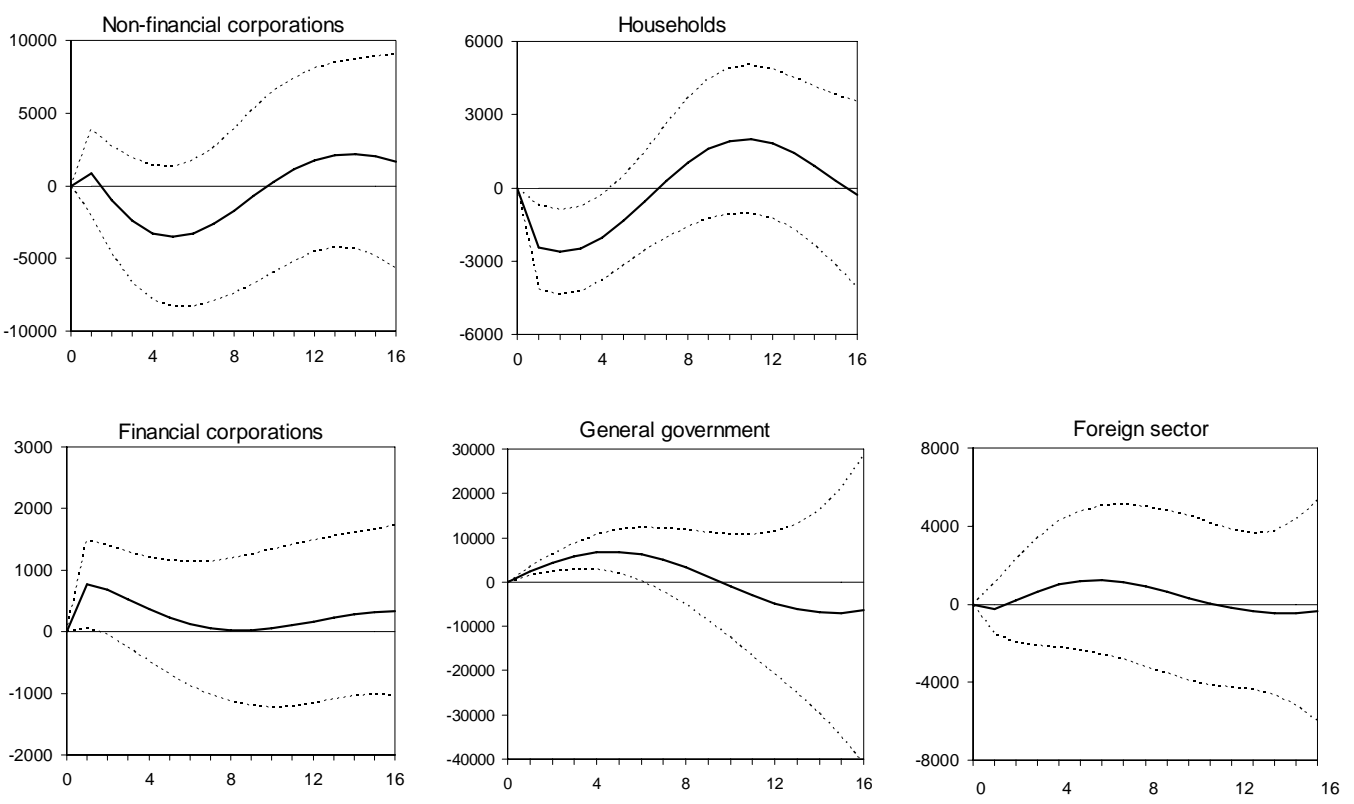

See note to Figure 6. 
Figure 10: impact of a contractionary monetary policy shock on firm assets and liabilities

(deviation from the baseline; millions of 1995 EUR)

\section{(a) financial liabilities}
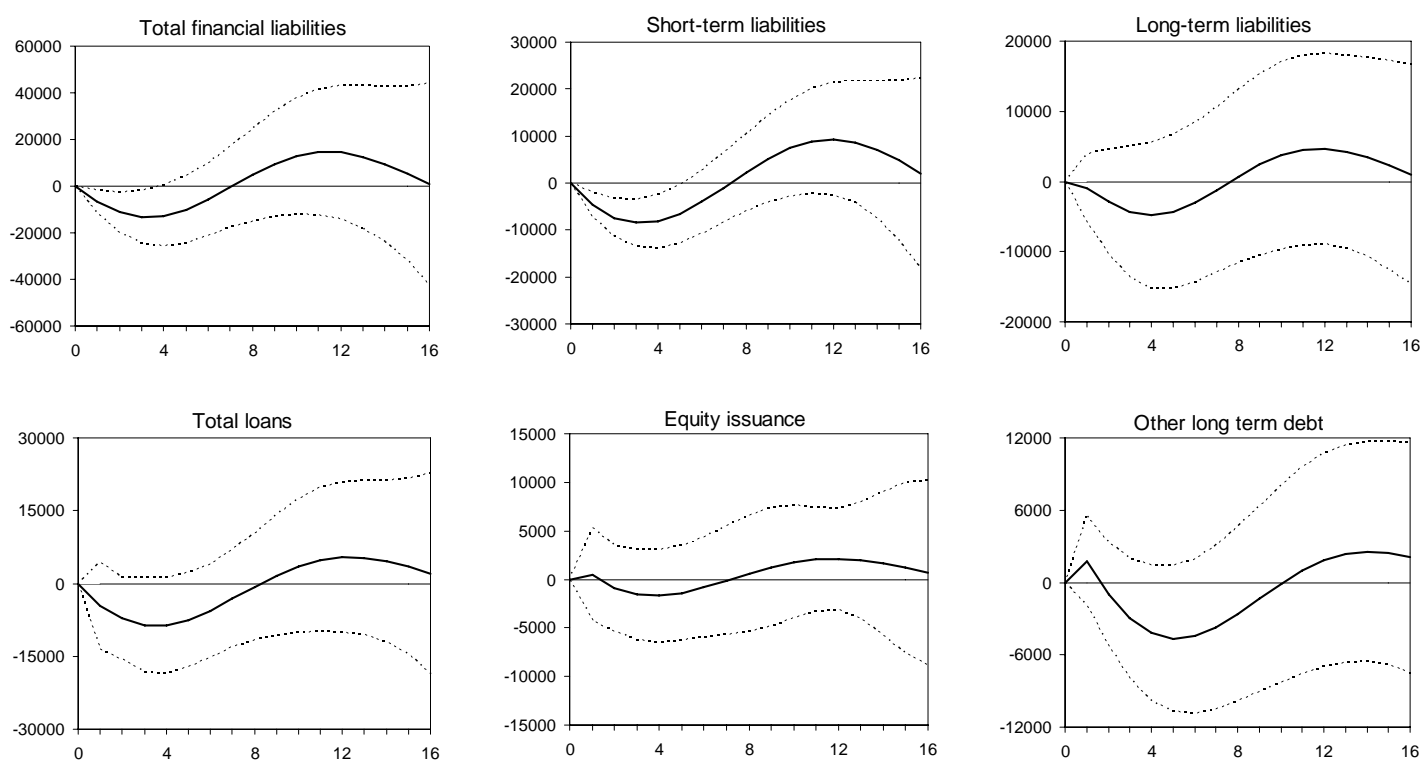

(b) financial assets
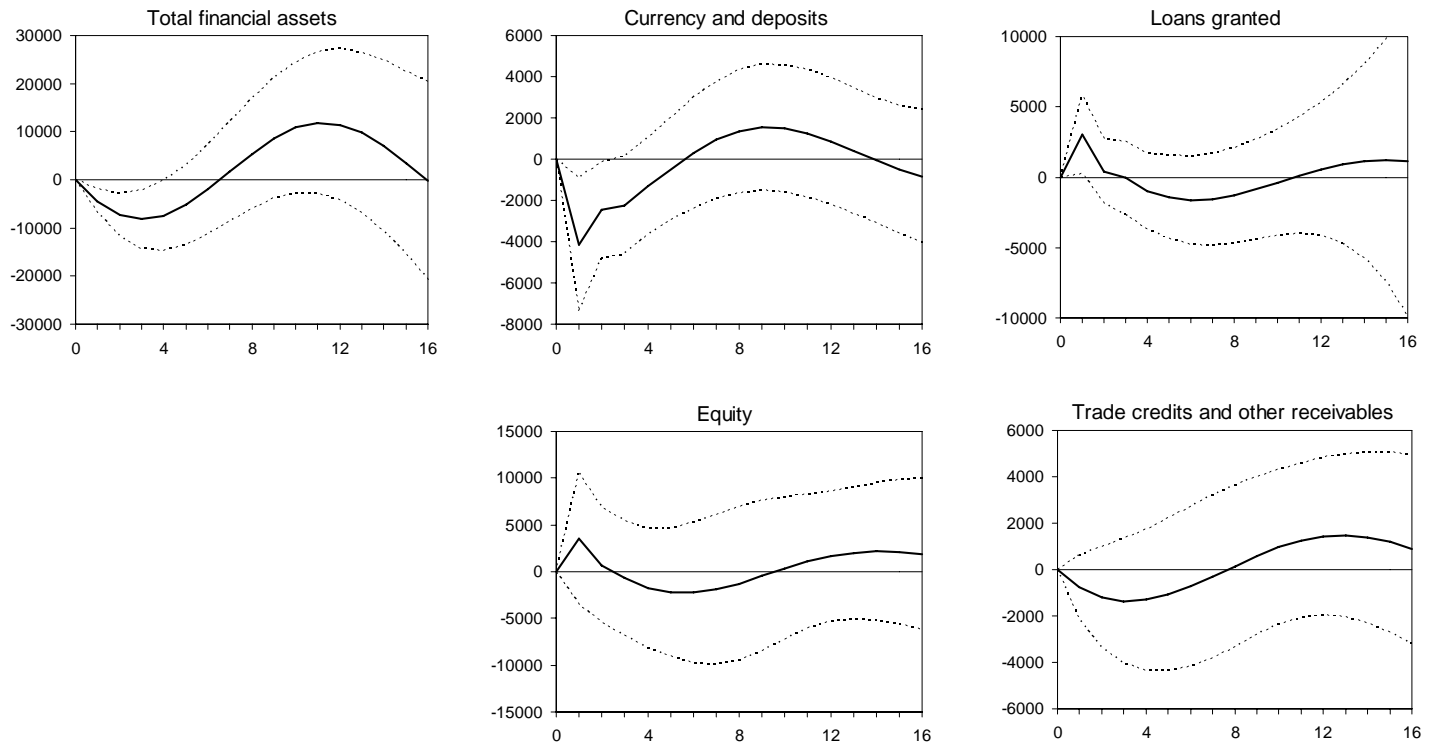

See note to Figure 6.

Long-term liabilities are the sum of Equity and Other long term debt; the latter comprises securities and loans both with maturity over one year. 
Figure 11: impact of a contractionary monetary policy shock on household assets and liabilities

(deviation from the baseline; millions of 1995 EUR)
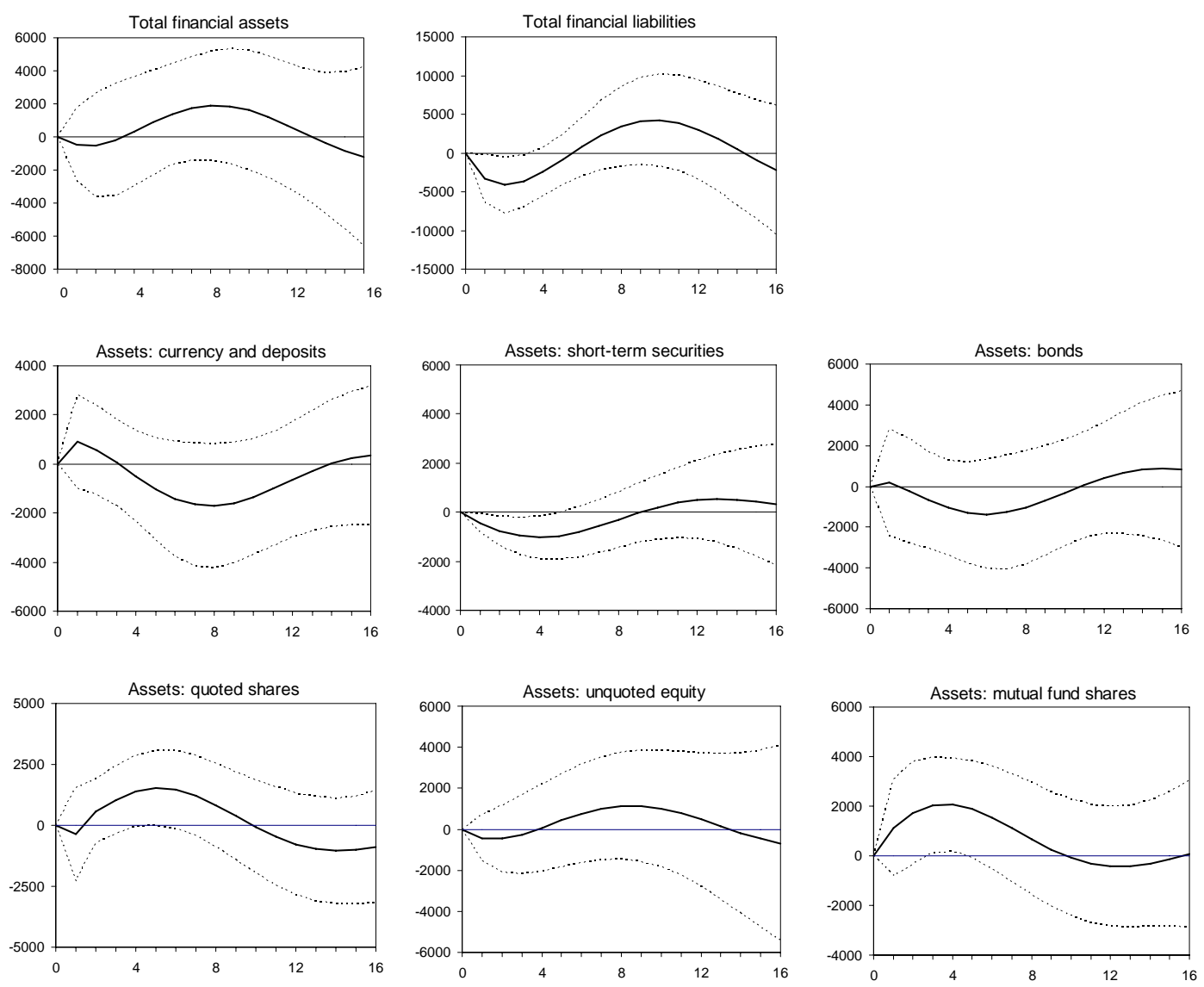

See note to Figure 6. 
Figure 12: impact of a contractionary monetary policy shock on the other sectors of the economy

(deviation from the baseline; millions of 1995 EUR)
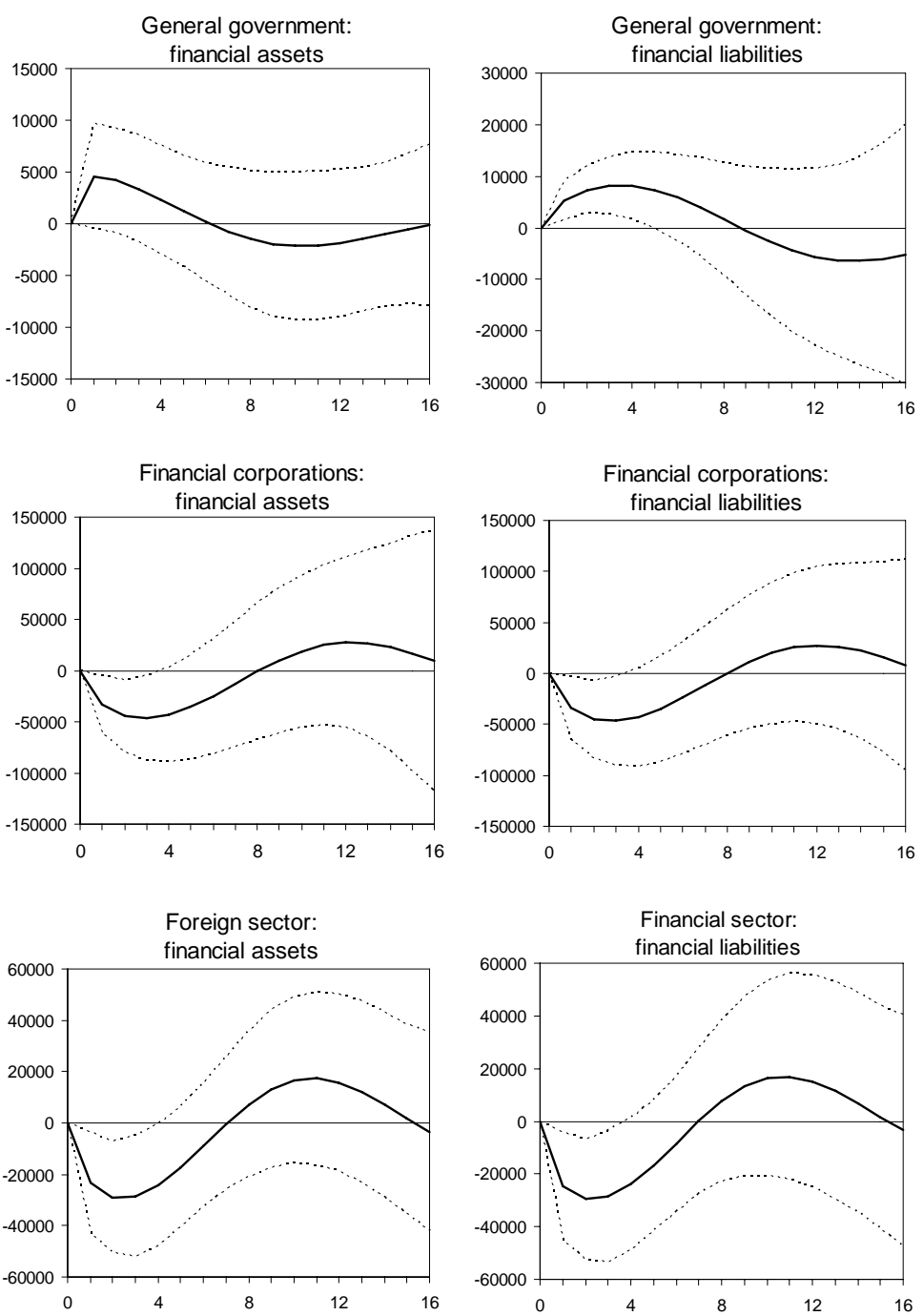

See note to Figure 6. 
Figure 13: impact of a contractionary monetary policy shock on total loans (deviation from the baseline; millions of 1995 EUR)
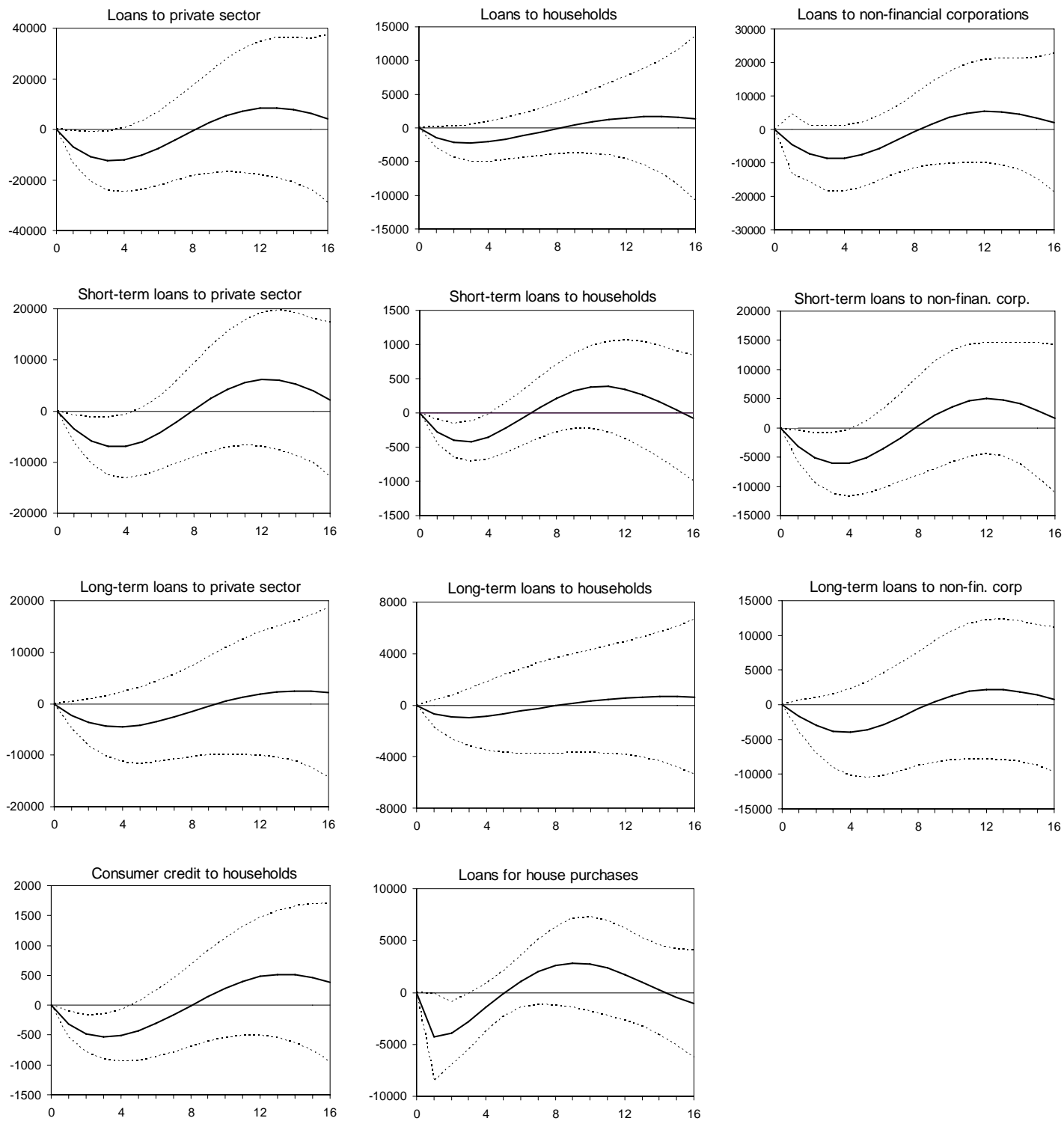

See note to Figure 6. 
Figure 14: loans to households and firms, total, bank and non-bank loans (quarterly flows 1999Q1-2009Q2; billions of euros at current prices)
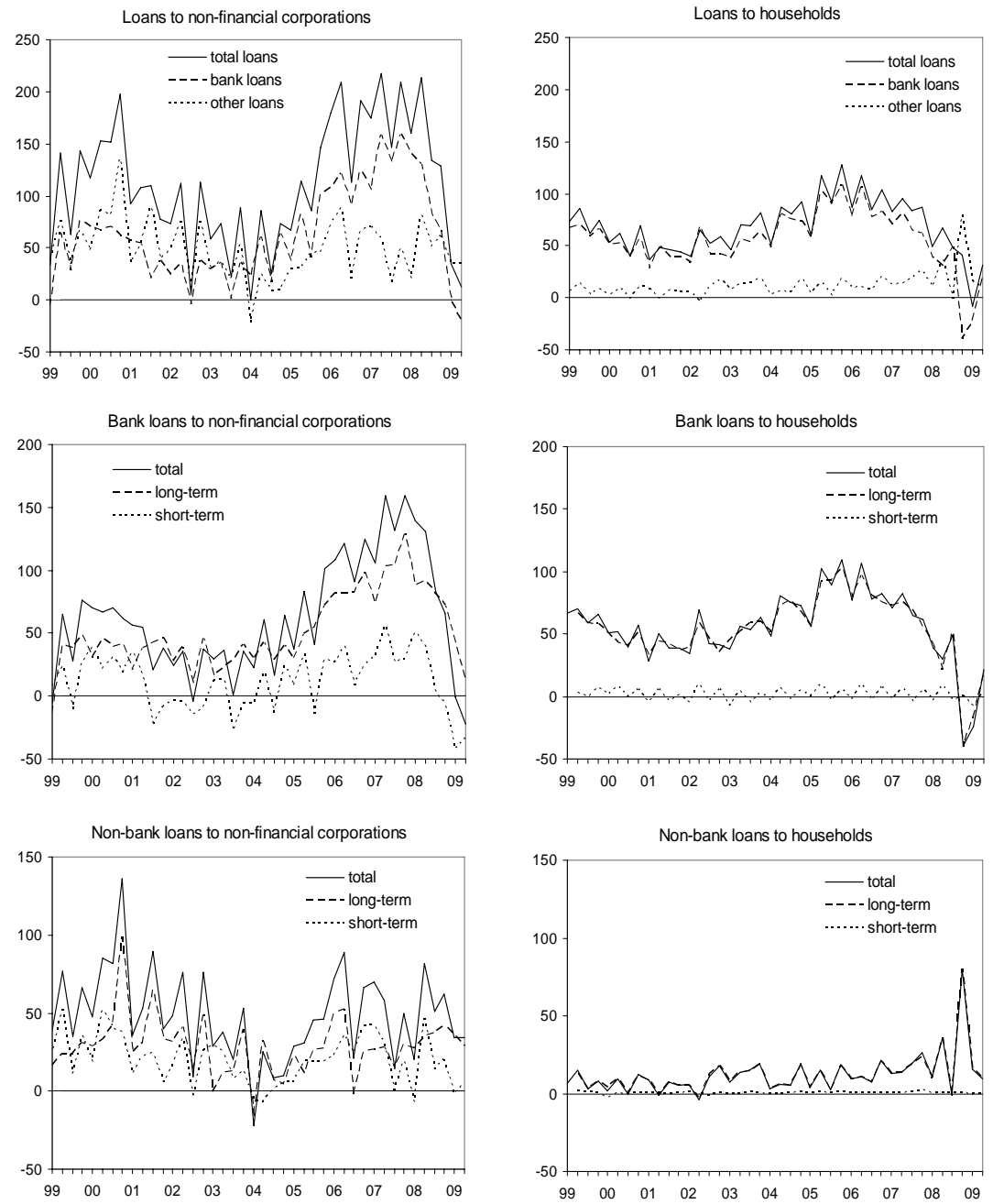
Figure 15, impact of a contractionary monetary policy shock on bank loans (deviation from the baseline; millions of 1995 EUR)
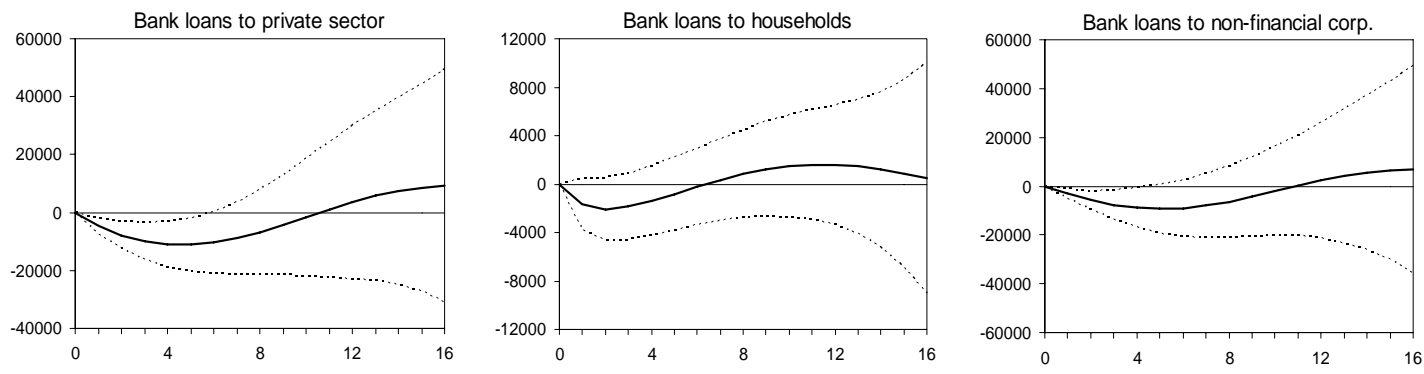

See note to Figure 6

Figure 16: impact of a contractionary monetary policy shock on non-bank loans (deviation from the baseline; millions of 1995 EUR)
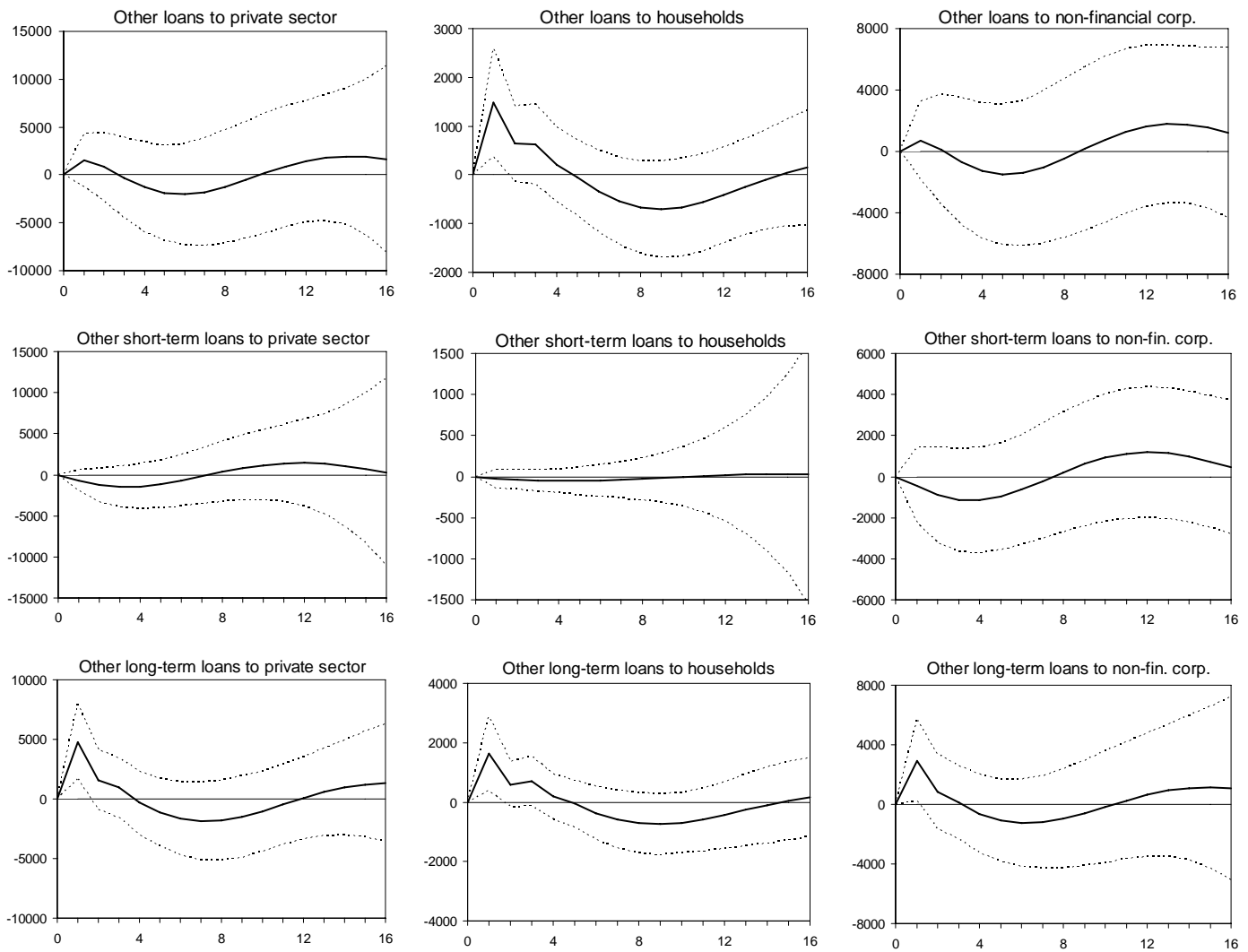

See note to Figure 6. 
Table 1: VAR lag order selection

\begin{tabular}{ccccccc}
\hline \hline Lag & LogL & LR & FPE & AIC & SC & HQ \\
\hline 0 & 156.82 & NA & $3.04 \mathrm{E}-09$ & -8.26 & -8.09 & -8.20 \\
1 & 393.44 & $409.30^{*}$ & $2.02 \mathrm{E}-14^{*}$ & $-20.18^{*}$ & $-19.31^{*}$ & $-19.87^{*}$ \\
2 & 408.54 & 22.85 & $2.20 \mathrm{E}-14$ & -20.14 & -18.57 & -19.58 \\
3 & 422.67 & 18.33 & $2.65 \mathrm{E}-14$ & -20.04 & -17.77 & -19.24 \\
4 & 439.45 & 18.14 & $3.02 \mathrm{E}-14$ & -20.08 & -17.12 & -19.03 \\
5 & 457.07 & 15.24 & $3.78 \mathrm{E}-14$ & -20.17 & -16.51 & -18.88 \\
\hline \hline
\end{tabular}

$\left(^{*}\right)$ indicates lag order selected by the specific criterion. $L R$ : sequential modified likelihood ratio test statistic (each test at 5\% level); FPE: Final prediction error; AIC: Akaike information criterion; SC: Schwarz information criterion; HQ: Hannan-Quinn information criterion.

Table 2: autocorrelation LM test ( $H_{0}$ : there is no serial correlation at specified lag)

\begin{tabular}{ccc}
\hline \hline Lags & LM-Stat & Prob. \\
\hline 1 & 22.107 & 0.140 \\
2 & 26.505 & 0.057 \\
3 & 19.319 & 0.253 \\
4 & 13.589 & 0.629 \\
5 & 14.318 & 0.575 \\
6 & 20.137 & 0.214 \\
7 & 14.190 & 0.585 \\
8 & 29.434 & 0.048 \\
\hline \hline
\end{tabular}

Probabilities from chi-square with 16 d.f. 
Table 3: VAR residual normality test

\begin{tabular}{ccccc}
\hline \hline Component & Skewness & Chi-sq & df & Prob. \\
\hline$y$ & 0.374 & 0.954 & 1 & 0.329 \\
$p$ & 0.129 & 0.114 & 1 & 0.735 \\
pcom & 0.043 & 0.013 & 1 & 0.910 \\
int & 0.086 & 0.050 & 1 & 0.823 \\
Joint & & 1.132 & 4 & 0.889 \\
\hline \hline Component & Kurtosis & Chi-sq & df & Prob. \\
\hline$y$ & 3.220 & 0.083 & 1 & 0.773 \\
$p$ & 2.090 & 1.413 & 1 & 0.235 \\
pcom & 1.724 & 2.780 & 1 & 0.096 \\
int & 1.880 & 2.145 & 1 & 0.143 \\
Joint & & 6.421 & 4 & 0.170 \\
\hline \hline Component & Jarque-Bera & df & Prob. & \\
\hline$y$ & 1.037 & 2 & 0.595 & \\
$p$ & 1.527 & 2 & 0.466 & \\
pcom & 2.793 & 2 & 0.248 & \\
int & 2.195 & 2 & 0.334 & \\
Joint & 7.552 & 8 & 0.478 & \\
\hline \hline
\end{tabular}

Cholesky orthogonalisation; the null hypothesis is that residuals follow a multivariate Normal distribution. 
Table 4: flow-of-funds variables, IRFs and descriptive statistics (quarterly flow series in billions of 1995 EUR, seasonally adjusted)

\begin{tabular}{|c|c|c|c|c|c|c|c|c|c|}
\hline \multirow{3}{*}{ Variable } & \multicolumn{6}{|c|}{ FoF variable descriptive statistics } & \multicolumn{3}{|c|}{ Peak response } \\
\hline & $\begin{array}{c}\text { Mean } \\
\text { (with sign) }\end{array}$ & $\begin{array}{c}\text { Mean } \\
\text { (abs.values) }\end{array}$ & Median & Max & Min & Std. Dev. & $\begin{array}{c}\text { Billions } \\
\text { of } € 1995\end{array}$ & $\begin{array}{c}\text { Delay } \\
\text { (quarters) }\end{array}$ & $\begin{array}{l}\text { As a \% of } \\
\text { average flow }\end{array}$ \\
\hline & & (a) & & & & & (b) & & (b) /(a) \\
\hline \multicolumn{10}{|l|}{ NON FINANCIAL CORPORATIONS } \\
\hline Net funds raised & 39.7 & 39.7 & 42.0 & 96.2 & 1.1 & 22.6 & -3.5 & 5 & -8.9 \\
\hline Financial assets, total & 146.2 & 146.2 & 146.4 & 256.3 & 50.6 & 51.5 & -8.2 & 3 & 5.6 \\
\hline currency and deposits & 20.6 & 23.1 & 21.0 & 57.2 & -23.7 & 17.7 & -4.1 & 1 & -18.0 \\
\hline loans granted & 36.5 & 36.5 & 35.7 & 77.9 & 5.2 & 16.9 & 3.0 & 1 & 8.3 \\
\hline shares and other equity & 63.6 & 64.1 & 63.3 & 236.1 & -9.7 & 40.9 & 3.5 & 1 & 5.4 \\
\hline trade credits and receive. & 23.2 & 29.4 & 24.8 & 55.6 & -34.2 & 21.7 & -4.7 & 5 & -6.4 \\
\hline Liabilities, total & 185.6 & 185.6 & 185.0 & 346.8 & 66.9 & 68.9 & -13.3 & 3 & -7.2 \\
\hline short-term liabilities & 48.9 & 52.2 & 53.0 & 113.6 & -35.2 & 34.0 & -8.5 & 3 & 16.3 \\
\hline long-term liabilities & 136.5 & 136.5 & 137.7 & 266.2 & 71.2 & 43.9 & -4.8 & 4 & -3.5 \\
\hline shares and other equity & $\begin{array}{r}61.6 \\
61.6\end{array}$ & $\begin{array}{r}61.6 \\
61.6\end{array}$ & $\begin{array}{r}57.6 \\
57.6\end{array}$ & 196.5 & 9.3 & 32.4 & -1.7 & 4 & -2.7 \\
\hline other long-term debt & 72.9 & 72.9 & 72.6 & 122.7 & 11.8 & 28.4 & -4.7 & 5 & -6.4 \\
\hline \multicolumn{10}{|l|}{ HOUSEHOLDS } \\
\hline Net funds raised & -55.3 & 55.3 & -51.8 & -31.9 & -89.5 & 12.7 & -2.6 & 2 & -4.8 \\
\hline Financial assets, total & 119.6 & 119.6 & 117.6 & 150.7 & 87.2 & 17.0 & 1.9 & 8 & 1.6 \\
\hline currency and deposits & 47.6 & 47.7 & 49.7 & 98.0 & -2.1 & 19.9 & -1.7 & 8 & -3.6 \\
\hline short-term securities & -0.6 & 3.5 & -0.1 & 6.3 & -9.2 & 4.2 & -1.0 & 4 & -29.3 \\
\hline long-term securities & 10.3 & 14.5 & 11.9 & 43.4 & -21.7 & 14.5 & -1.4 & 6 & -9.4 \\
\hline quoted shares & -2.5 & 9.8 & -0.1 & 24.9 & -28.0 & 11.9 & 1.5 & 5 & 15.6 \\
\hline mutual fund shares & 6.5 & 14.9 & 4.2 & 63.9 & -34.0 & 19.7 & 2.1 & 4 & 13.8 \\
\hline unquoted shares & 2.3 & 6.4 & 2.5 & 17.6 & -16.6 & 8.0 & 1.1 & 8 & 17.8 \\
\hline Liabilities, total & 64.3 & 64.6 & 66.6 & 110.0 & -6.5 & 22.8 & 4.2 & 2 & 6.6 \\
\hline \multicolumn{10}{|l|}{ GENERAL GOVERNMENT } \\
\hline Net funds raised & 33.4 & 33.9 & 35.0 & 98.8 & -10.9 & 21.1 & 6.8 & 5 & 20.1 \\
\hline Financial. assets, total & 19.4 & 25.1 & 16.2 & 153.2 & -33.5 & 30.6 & 4.6 & 1 & 18.3 \\
\hline Liabilities, total & 53.5 & 53.5 & 42.2 & 183.8 & 6.5 & 38.5 & 8.2 & 3 & 15.3 \\
\hline \multicolumn{10}{|l|}{ FINANCIAL CORPORATIONS } \\
\hline Net funds raised & -14.6 & 14.6 & -17.0 & 0.7 & -28.3 & 7.9 & 0.8 & 1 & 5.3 \\
\hline Financial. assets, total & 447.3 & 447.3 & 428.2 & 1006.2 & 53.6 & 221.2 & -46.8 & 3 & -10.5 \\
\hline Liabilities, total & 432.8 & 432.8 & 415.7 & 1022.0 & 35.9 & 220.4 & -46.8 & 3 & -10.8 \\
\hline \multicolumn{10}{|l|}{ FOREIGN SECTOR } \\
\hline Net funds raised & -3.2 & 11.0 & 0.0 & 18.3 & -34.0 & 13.6 & 1.2 & 6 & 11.2 \\
\hline Financial. assets, total & 201.6 & 219.1 & 209.3 & 489.3 & -199.1 & 136.4 & -29.0 & 2 & -13.2 \\
\hline Liabilities, total & 198.4 & 219.6 & 204.2 & 492.5 & -228.5 & 141.0 & -29.7 & 2 & -13.5 \\
\hline \multicolumn{10}{|l|}{ TOTAL LOANS } \\
\hline to private sector, total & 152.0 & 152.0 & 155.9 & 261.4 & 25.8 & 54.6 & -12.3 & 3 & 8.1 \\
\hline short-term & 28.5 & 33.2 & 31.8 & 90.0 & -40.2 & 26.6 & -6.9 & 4 & -20.8 \\
\hline long-term & 123.6 & 123.6 & 117.2 & 183.2 & 60.7 & 31.3 & -4.5 & 4 & -3.7 \\
\hline to non financial corp., total & 94.5 & 94.5 & 89.5 & 243.3 & 5.4 & 56.0 & -8.6 & 4 & -9.2 \\
\hline short-term & 26.7 & 31.2 & 28.6 & 87.0 & -38.3 & 25.4 & -6.0 & 3 & -19.4 \\
\hline long-term & 67.2 & 67.2 & 66.9 & 117.8 & 25.8 & 25.7 & -4.0 & 4 & -5.9 \\
\hline to households, total & 58.0 & 58.0 & 59.5 & 92.9 & 12.4 & 18.7 & -2.2 & 3 & -3.8 \\
\hline short-term & 1.8 & 2.2 & 2.0 & 7.9 & -2.6 & 2.1 & -0.4 & 3 & -18.6 \\
\hline long-term & 56.2 & 56.2 & 57.6 & 86.9 & 13.1 & 17.3 & -1.0 & 3 & -1.7 \\
\hline for consumer credit & 5.4 & 5.6 & 5.9 & 9.5 & -1.1 & 2.7 & -0.5 & 3 & -9.5 \\
\hline for house purchase & 39.3 & 41.3 & 41.1 & 78.1 & -28.6 & 19.7 & -4.3 & 1 & -10.4 \\
\hline \multicolumn{10}{|l|}{ BANK LOANS } \\
\hline to private sector & 101.8 & 102.7 & 100.2 & 173.2 & -17.6 & 45.5 & -11.2 & 5 & -10.9 \\
\hline to non financial corporations & 52.5 & 53.6 & 46.2 & 117.7 & -22.9 & 34.0 & -9.3 & 5 & -17.4 \\
\hline to households & 48.0 & 48.7 & 50.0 & 83.5 & -9.6 & 20.5 & -2.1 & 2 & -4.3 \\
\hline \multicolumn{10}{|l|}{ OTHER LOANS (NON-BANK) } \\
\hline to private sector, total & 52.0 & 52.0 & 51.5 & 108.1 & 7.2 & 20.2 & -2.0 & 6 & -3.9 \\
\hline short-term & 17.6 & 18.0 & 18.1 & 41.1 & -5.8 & 11.5 & -1.4 & 3 & -8.0 \\
\hline long-term & 34.9 & 35.1 & 33.9 & 83.9 & -3.6 & 17.8 & 4.8 & 1 & 13.7 \\
\hline to non financial corp., total & 41.9 & 41.9 & 43.4 & 101.0 & 0.3 & 20.1 & -1.5 & 5 & -3.6 \\
\hline short-term & 17.2 & 18.0 & 16.5 & 42.5 & -13.2 & 12.8 & -1.2 & 4 & -6.5 \\
\hline long-term & 24.4 & 25.3 & 22.5 & 90.8 & -13.9 & 17.1 & 2.9 & 1 & 11.6 \\
\hline to households, total & 10.1 & 10.1 & 8.6 & 42.0 & -1.1 & 7.5 & 1.5 & 1 & 14.7 \\
\hline short-term & 0.2 & 0.5 & 0.2 & 2.2 & -2.0 & 0.7 & -0.1 & 5 & -11.3 \\
\hline long-term & 9.7 & 9.8 & 8.5 & 50.2 & -1.4 & 8.6 & 1.6 & 1 & 16.7 \\
\hline
\end{tabular}

Note: the peak IRF response is reported in billions of 1995 EUR and as a percentage of the mean of the flow-of-funds variable, together with the number of quarters following the shock. 
